\title{
Modulation of p53 activity by $\mathrm{I} \kappa \mathrm{B} \alpha$ : Evidence suggesting a common phylogeny between NF- $\kappa B$ and p53 transcription factors David H Dreyfus ${ }^{\dagger 1,2}$, Masayuki Nagasawa ${ }^{\dagger 1,3}$, Erwin W Gelfand ${ }^{1}$ and Lucy Y Ghoda*4
}

\begin{abstract}
Address: ${ }^{1}$ Division of Basic Sciences, Department of Pediatrics, National Jewish Medical Research Center, Denver, CO 80262 USA, ${ }^{2}$ Department of Pediatrics, Yale University School of Medicine, New Haven, CT, USA, ${ }^{3}$ Departments of Pediatrics and Developmental Biology, Postgraduate School, Tokyo Medical and Dental University, Tokyo, Japan and ${ }^{4}$ The Webb-Waring Institute for Cancer, Aging, and Antioxidant Research and the Department of Medicine, the University of Colorado at Denver and Health Sciences Center, Denver CO 80262 USA; To whom correspondence should be addressed at The Webb-Waring Institute, UCDHSC, Box C321, 4200 East Ninth Ave., Denver, CO 80262 USA
\end{abstract}

Email: David H Dreyfus - dhdreyfus@pol.net; Masayuki Nagasawa - mnagasawa.ped@tmd.ac.jp; Erwin W Gelfand - gelfande@njc.org; Lucy Y Ghoda* - lucy.ghoda@uchsc.edu

* Corresponding author †Equal contributors

Published: 21 June 2005

BMC Immunology 2005, 6:12 doi:10.1 186/147|-2172-6-12
Received: 27 October 2004

Accepted: 21 June 2005

This article is available from: http://www.biomedcentral.com/I47I-2I72/6/12

(c) 2005 Dreyfus et al; licensee BioMed Central Ltd.

This is an Open Access article distributed under the terms of the Creative Commons Attribution License (http://creativecommons.org/licenses/by/2.0), which permits unrestricted use, distribution, and reproduction in any medium, provided the original work is properly cited.

\begin{abstract}
Background: In this work we present evidence that the $\mathrm{p} 53$ tumor suppressor protein and NF- $\mathrm{KB}$ transcription factors could be related through common descent from a family of ancestral transcription factors regulating cellular proliferation and apoptosis. P53 is a homotetrameric transcription factor known to interact with the ankyrin protein 53BP2 (a fragment of the ASPP2 protein). NF- $\mathrm{KB}$ is also regulated by ankyrin proteins, the prototype of which is the $I \kappa B$ family. The DNA binding sequences of the two transcription factors are similar, sharing 8 out of 10 nucleotides. Interactions between the two proteins, both direct and indirect, have been noted previously and the two proteins play central roles in the control of proliferation and apoptosis.

Results: Using previously published structure data, we noted a significant degree of structural alignment between $\mathrm{p} 53$ and NF- $\mathrm{KB} p 65$. We also determined that $I \kappa B \alpha$ and $\mathrm{p} 53$ bind in vitro through a specific interaction in part involving the DNA binding region of $p 53$, or a region proximal to it, and the amino terminus of $I \kappa B \alpha$ independently or cooperatively with the ankyrin 3 domain of $I \kappa B \alpha \ln$ cotransfection experiments, $\kappa B \alpha$ could significantly inhibit the transcriptional activity of $p 53$. Inhibition of $p 53$-mediated transcription was increased by deletion of the ankyrin 2, 4, or 5 domains of $I \kappa B \alpha$ Co-precipitation experiments using the stably transfected ankyrin 5 deletion mutant of $\kappa B \alpha$ and endogenous wild-type p53 further support the hypothesis that $\mathrm{p} 53$ and $\mathrm{IKB} \alpha$ can physically interact in vivo.

Conclusion: The aggregate results obtained using bacterially produced $I \kappa B \alpha$ and $p 53$ as well as reticulocyte lysate produced proteins suggest a correlation between in vitro co-precipitation in at least one of the systems and in vivo $p 53$ inhibitory activity. These observations argue for a mechanism involving direct binding of $I \kappa B \alpha$ to $p 53$ in the inhibition of p53 transcriptional activity, analogous to the inhibition of NF$\kappa B$ by $\kappa B \alpha$ and $p 53$ by $53 B$ P2/ASPP2. These data furthermore suggest a role for ankyrin proteins in the regulation of $\mathrm{p} 53$ activity. Taken together, the NFKB and $\mathrm{p} 53$ proteins share similarities in structure, DNA binding sites and binding and regulation by ankyrin proteins in support of our hypothesis that the two proteins share common descent from an ancestral transcriptional factor.
\end{abstract}




\section{Background}

In this work we present evidence that the p53 tumor suppressor and NF- $\mathrm{KB}$ transcription factors could be related through common descent from a family of ancestral transcription factors regulating cellular proliferation and apoptosis. P53 and related proteins are transcription factors that regulate DNA repair and cellular apoptosis in response to stress and injury, notably those resulting in DNA damage [1-4]. Although it is a non-essential gene, loss of p53 function in humans through hereditary syndromes is associated with a markedly increased rate of malignancy. Furthermore, over 50\% of malignancies have mutated p53 alleles [5]. These observations suggest p53 and related proteins function as a checkpoint for malignant transformation either by repairing DNA damage or by eliminating cells with irreparably damaged DNA [6-8]

P53 is a homotetrameric transcription factor that binds a consensus sequence 5' RRRRC(A/T)(T/A)GYYY-3' (where $\mathrm{R}$ indicates purine, $\mathrm{A}$ or $\mathrm{G}$; and $\mathrm{Y}$ indicates pyrimidine, $\mathrm{C}$ or T)[9]. The consensus sequence is usually present as a dimer in p53 inducible gene promoters such as the $\mathrm{p} 21^{\mathrm{WAF} 1}$ protein regulating cell cycle progression [10]. P53 protein can be divided into three functional domains, the amino-terminal activation domain encompassing amino acids 1-43, the core sequence-specific DNA-binding domain (amino acids 100-300), and the multi-functional carboxy-terminal domain (amino acids 300-393) $[11,12]$. Point mutations in p53 identified in malignant cells are clustered around volutionarily conserved regions in the DNA binding region of p53 and simultaneously eliminate both sequence-specific DNA binding and transcriptional activity [12-14].

P53 is regulated on multiple levels including post-translationally by modifications such as acetylation, phosphorylation, protein degradation, and protein-protein interaction $[15,16]$. Phosphorylation of p53 induces conformational changes that alter interactions with regulatory proteins such as MDM2, which in turn can regulate p53 stability, and can also activate site-specific DNA binding activity [17-22]. Additional cellular proteins that bind to $\mathrm{p} 53$ include proteins of the general transcription machinery such as CBP/p300 [23,24]. CBP/p300 binding to $\mathrm{p} 53$ regulates acetylation and p53 transcriptional activation $[25,26]$. P53 is also regulated through association with ankyrin repeat proteins such as p53 binding protein 1 (53 BP1) and p53 binding protein 2 (53BP2, now known to be a fragment of apoptosis stimulating protein of p53 or ASPP2) [27] and gankyrin [28,29]. Thus, it is likely that p53 is modulated by association with and/or modification by a variety of regulatory proteins including kinases, transcription factors, and ankyrin-containing proteins. In addition, viral proteins also bind to and modify p53 and may contribute to malignant transformation of infected cells by viruses such as papilloma [30,31], cytomegalovirus [32], and Epstein-Barr virus (EBV)[33,34].

$\mathrm{NF}-\kappa \mathrm{B}$ transcription factors also play a central role in the control of apoptosis [35-37]. NF- $\mathrm{BB}$ transcription factors bind to the consensus sequence 5'-GGRNNYYCC-3' in the promoters of both cellular and viral genes [38,39]. The RelA/p65 subunit of NF- $\kappa B$ is regulated by the ankyrin repeat protein $\mathrm{I} \kappa \mathrm{B} \alpha$ which masks the nuclear localization signal of the p65/p50 NF- $\kappa \mathrm{B}$ heterodimer $[40,41]$. NF- $\kappa \mathrm{B}-$ inducing signals are transmitted from the cell surface to the cytoplasm resulting in site-specific phosphorylation at two sites in the N-terminus of IKB $\alpha$ [42-45], conjugation of ubiquitin molecules to I $\mathrm{I} B \alpha$, and subsequent degradation of ubiquitinated $\mathrm{I} \kappa \mathrm{B} \alpha$ by the $26 \mathrm{~S}$ proteasome complex [46-49]. Degradation of $\mathrm{I} \kappa \mathrm{B} \alpha$ in turn unmasks the nuclear localization signal of p50/p65 followed by translocation of the active transcription factor to the nucleus. Other NF- $\kappa$ B subunits including a homodimer of the p50

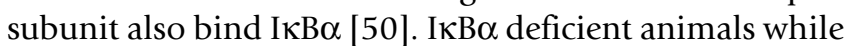
viable, die of uncontrolled inflammation in infancy, and mice overexpressing I $\mathrm{KB} \alpha$ display an abnormal immunologic repertoire suggesting that a major physiologic role of $\mathrm{I} \kappa \mathrm{B} \alpha$ is to limit immune and inflammatory responses through a feedback pathway $[35,51,52]$.

Interactions between p53 and NF- $\mathrm{B}$ h have been noted, for example both factors compete for a binding site in the regulatory factor CBP/p300 [53]. Transfection of a constitutively active form of $\mathrm{I} \kappa \mathrm{B} \alpha$ protein can block p53 dependent cell death [54-56] and p53 regulatory factors can modulate NF- $\kappa B$ pathways [57-59]. Not only are p53 and $\mathrm{NF}-\kappa \mathrm{B}$ transcription coregulated under a variety of physiological conditions, but similarity has been noted between the crystal structures of p53 and NF- $\kappa \mathrm{B}$ p 50 [14,60-62]. Both proteins contain a similarly sited zinc atom that coordinates site specific DNA binding and similar secondary and tertiary organization, but no primary amino acid similarity was noted between the two proteins. Furthermore, p65 has been shown to bind the ankyrin protein p53-binding protein 2 (53BP2). 53BP2 has been shown to be a fragment of a larger protein, ASPP2, that promotes the apoptotis-inducing effects of p53 [27]. P65 apparently inhibits p53-mediated apoptosis by binding to 53BP2/ASSP2 [63]. As with p53, NF-кB transcription is altered by viral pathogens [64-67].

In this work, we present evidence for the specific binding of the NF- $\kappa \mathrm{B}$ inhibitor and ankyrin protein, $\mathrm{I} \kappa \mathrm{B} \alpha$, to $\mathrm{p} 53$. A physical interaction between p53 and $\mathrm{I} \kappa \mathrm{B} \alpha$ was also reported by Chang [68], as well as Zhou, et al. [69], and was shown to be regulated by proapoptotic and growth suppressing stimuli. Our studies show the binding interaction to involve both ankyrin and non-ankyrin 
sequences in the I $\mathrm{B} \mathrm{B} \alpha$ protein, and the DNA binding core domain of p53. We demonstrate that transient expression of $\mathrm{I} \kappa \mathrm{B} \alpha$ is associated with NF- $\kappa \mathrm{B}$ independent decreases in p53 mediated transcription of a p53 reporter gene in vivo. These observations were made in Akata cells, an EBVgenome positive lymphoblastoid cell line originally derived from a Burkitts lymphoma. Akata cells lack endogenous functional p53 [33]. We propose that the binding of the ankyrin protein $\mathrm{I} \kappa \mathrm{B} \alpha$ to p53 is based upon the similarity in molecular structure of NF- $\kappa \mathrm{B}$ and $\mathrm{p} 53$.

\section{Results}

Similarity between $p 53$ and NF-KB transcription element binding sites

The hemi-dyad DNA consensus binding sites of p53 and $\mathrm{NF}-\kappa \mathrm{B}$ transcription factors are intriguingly similar as has been noted previously by Foo, et al., [70]; for p53, the binding site sequence is $5^{\prime}-\mathrm{RRRRC}(\mathrm{A} / \mathrm{T})(\mathrm{T} / \mathrm{A}) \mathrm{GYYY}-3^{\prime}$ and for NF- $\kappa B$ the binding site sequence is 5'- GGGRNNYYCC3 ' where $N, R$, and $Y$ indicate any nucleotide, purine (A or $\mathrm{G})$, and pyrimidine ( $\mathrm{C}$ or $\mathrm{T})$, respectively. Two changes in the nucleotide sequence of the $\mathrm{C}(\mathrm{A} / \mathrm{T})(\mathrm{A} / \mathrm{T}) \mathrm{G}$ core (underscored, above) of a p53 binding site is sufficient to generate the RNNY core (underscored, above) of a NF- $\mathrm{BB}$ binding site while sequences flanking the core are conserved. Depending on the specific sequences, these binding sites potentially encode a hairpin structure that could promote these nucleotide substitutions. Under these circumstances, only one mutagenic event would be necessary, since the second nucleotide exchange could occur by excision-repair following a mutagenic event in the first site. Based on this observation, we hypothesized that both regulatory factors shared descent from a common ancestral transcription factor, a proto-p53/NF-кB. An alternative possibility is that two independent families of transcription factors, proto-p53 and proto-NF- $\mathrm{\kappa B}$, converged to independently recognize a similar recognition sequence.

If both p53 and NF- $\mathrm{BB}$ descended from a common ancestral protein, they might retain the ability to bind to common proteins or proteins of related structures in addition to binding similar DNA sequences. With independent descent converging upon a similar DNA binding sequence no such common interactions would be expected. In support of descent from a common ancestral protein, the crystal structure of NF- $\mathrm{KB}$ p 65 aligns with that of p53 (Figure $1 \mathrm{~B}$ and $1 \mathrm{D}$, discussed below) a relationship that would not be expected unless the two proteins were related through phylogeny (descent) as well as ontogeny (function). Furthermore, numerous p53 binding proteins have in common the ankyrin repeat structure, a feature shared with the I $\kappa \mathrm{B}$ family of NF- $\kappa \mathrm{B}$ regulatory proteins.

\section{Structural alignment of p53 and p65 and ankyrin proteins, 53BP2 and $I K B \alpha$}

To test the hypothesis that p53 and p65 may share structural homology, the known crystal structures of both molecules were aligned using the program C3D4.1 [71]. P53 (Figure 1A) has previously been crystallized in association with the ankyrin protein 53BP2 (Figure 2C) [28]. Like $\mathrm{I} \kappa \mathrm{B} \alpha$ (Figure 2A), 53BP2 is also an ankyrin protein and has been identified as a fragment of a larger protein known as ASPP2 (apoptosis stimulating protein of p53) [27]. The structure of p65 (Figure 1C) is taken from the crystal structure of the dimer comprised of p65 and p50 in association with I $\kappa \mathrm{B} \alpha$ [50]. P65 has also been crystallized as a homodimer in association with $\operatorname{I\kappa B} \beta$ [72].

We used the information content algorithm of C3D4.1 which uses a BLOSUM62 based matrix to calculate conservation between the two pairs of proteins: p53 and p65 (Figure 1E); and $\mathrm{I} \kappa \mathrm{B} \alpha$ and 53BP2 (Figure 2E). The amino acids colored red in the aligned structures of $1 \mathrm{D}$ and $2 \mathrm{D}$ and the amino acid sequences of $1 \mathrm{E}$ and $2 \mathrm{E}$ depict regions of highest conservation while the grey areas are regions where there is no conservation. As shown by the regions of the two molecules colored red, we observed a surprising degree of structural alignment between the Rel homology domain of p65 and the p53 core domain, supposedly unrelated molecules (Figure 1D). The sequence alignment corresponding to the structures in $1 \mathrm{D}$ is depicted in $1 \mathrm{E}$.

Using these same methods, we aligned the structures of the ankyrin proteins, I $\mathrm{I} \mathrm{B} \alpha[50]$ and 53BP2 (Figure 2D and $2 \mathrm{E}$ ). The structure used for I $\mathrm{I} \mathrm{B} \alpha$ (Figure $2 \mathrm{~A}$ ) contains $71-$ 280 of the wild-type protein. We omitted the SH3 domain of the 53BP2 structure (Figure 2C) since it is not relevant to this report. The $\mathrm{I} \kappa \mathrm{B} \alpha$ protein contains six ankyrin motifs while the 53BP2 contains four. As expected, the two ankyrin proteins show a high degree of alignment. The fourth and $5^{\text {th }}$ ankyrins of $I \kappa \mathrm{B} \alpha$ are in very close alignment to the second and third ankyrins of 53BP2 (Figure $2 \mathrm{D})$. The sequences corresponding to these structures is shown in Figure 2E.

\section{Specific binding between I $\kappa B \alpha$ and $p 53$ occurs in vitro}

Purified I $\kappa \mathrm{B} \alpha$ protein was specifically labelled in vitro with [32P] using p90 rsk which we have previously shown to quantitatively phosphorylate $\mathrm{I} \kappa \mathrm{B} \alpha$. [32P] -labeled $\mathrm{I} \kappa \mathrm{B} \alpha$ was incubated with purified p53 (GST-p53) and precipitated either with glutathione/Sepharose (Seph-GSH) beads to bind the glutathione binding tag on GST-p53 or a p53-specific antibody (Ab2) and protein A/G beads. As shown in Figure 3, evidence of a specific association between purified bacterially-produced p53 and purified bacterially-produced wild-type $\mathrm{I} \kappa \mathrm{B} \alpha$ was observed in vitro (Fig. 2A). The conformation-specific p53 antibody (Ab5) does not recognize bacterially produced p53 


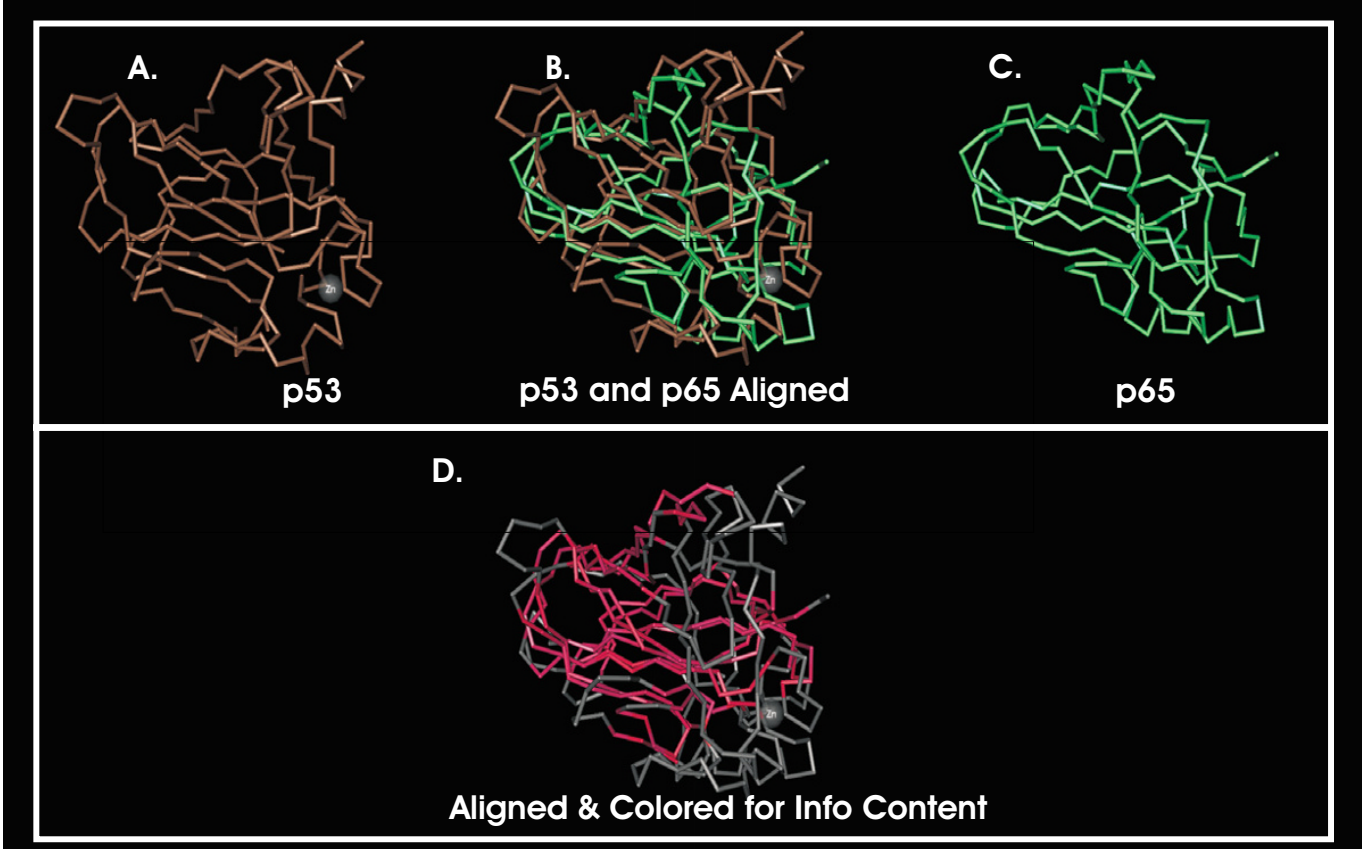

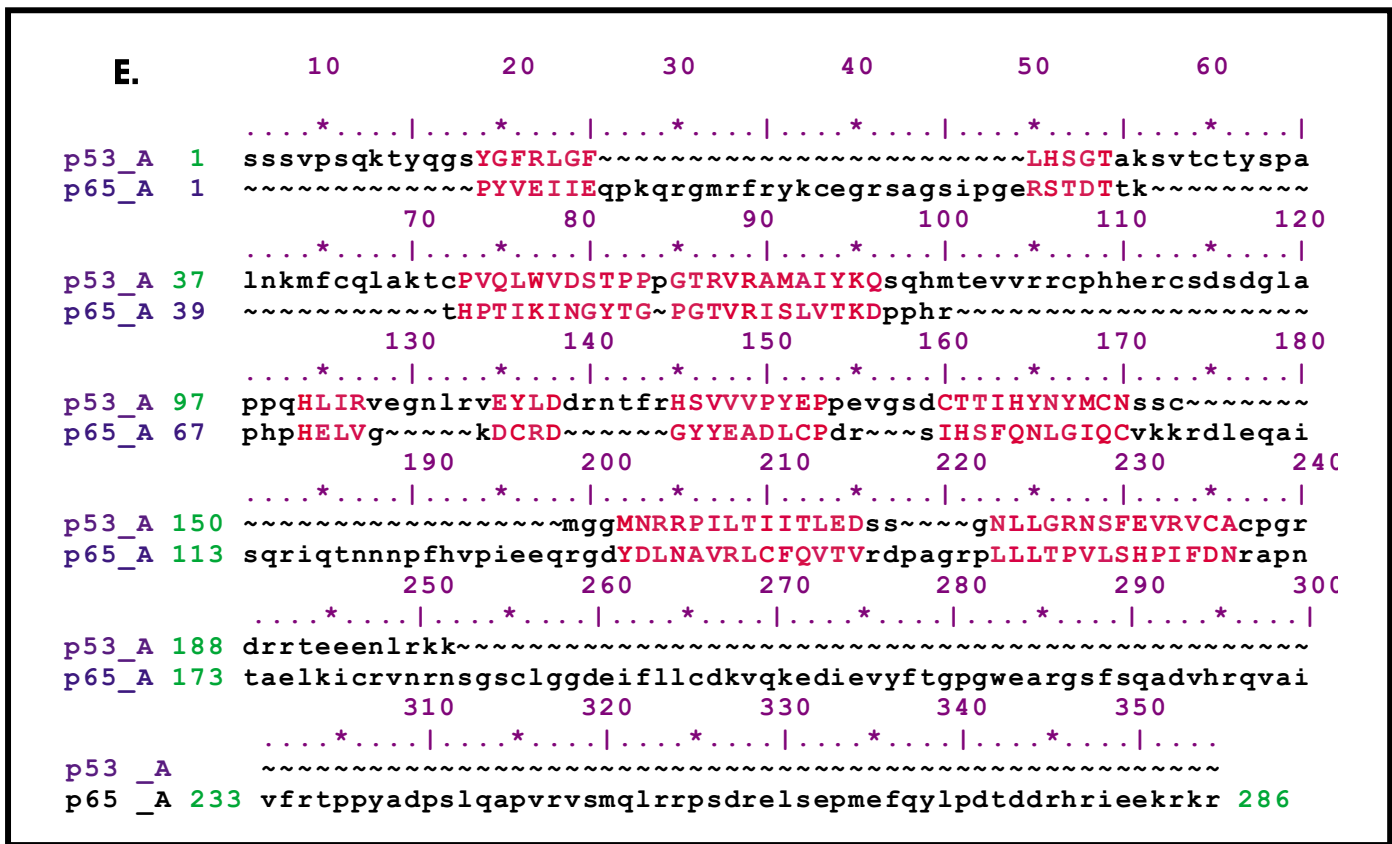

\section{Figure I}

Alignment of p53 (PDB ID:IYCS; IYCS_A dI) with p65 (PDB ID:IIKN; IIKN_A dI). A. The structures of p53 molecule (taken from the crystal structure of $p 53$ and $p 53$ binding protein 2); B. The aligned structures of $p 53$ and p65; C. The structure of the Rel homology domain of $p 65$ (taken from the crystal structure of the $p 65 / p 50$ heterodimer bound to I $\mathrm{B} \alpha$ ); $\mathrm{D}$. The aligned structures were colored according to information content based on a BLOSUM62 matrix to calculate conservation using the public domain program CN3D4.I [70]. A spectrum of red to blue is used to denote the degree of conservation where red is the most conserved. $\mathrm{E}$. The sequence alignment of p53 and p65 is depicted using the same coloring scheme as in the structure alignment in ID. 


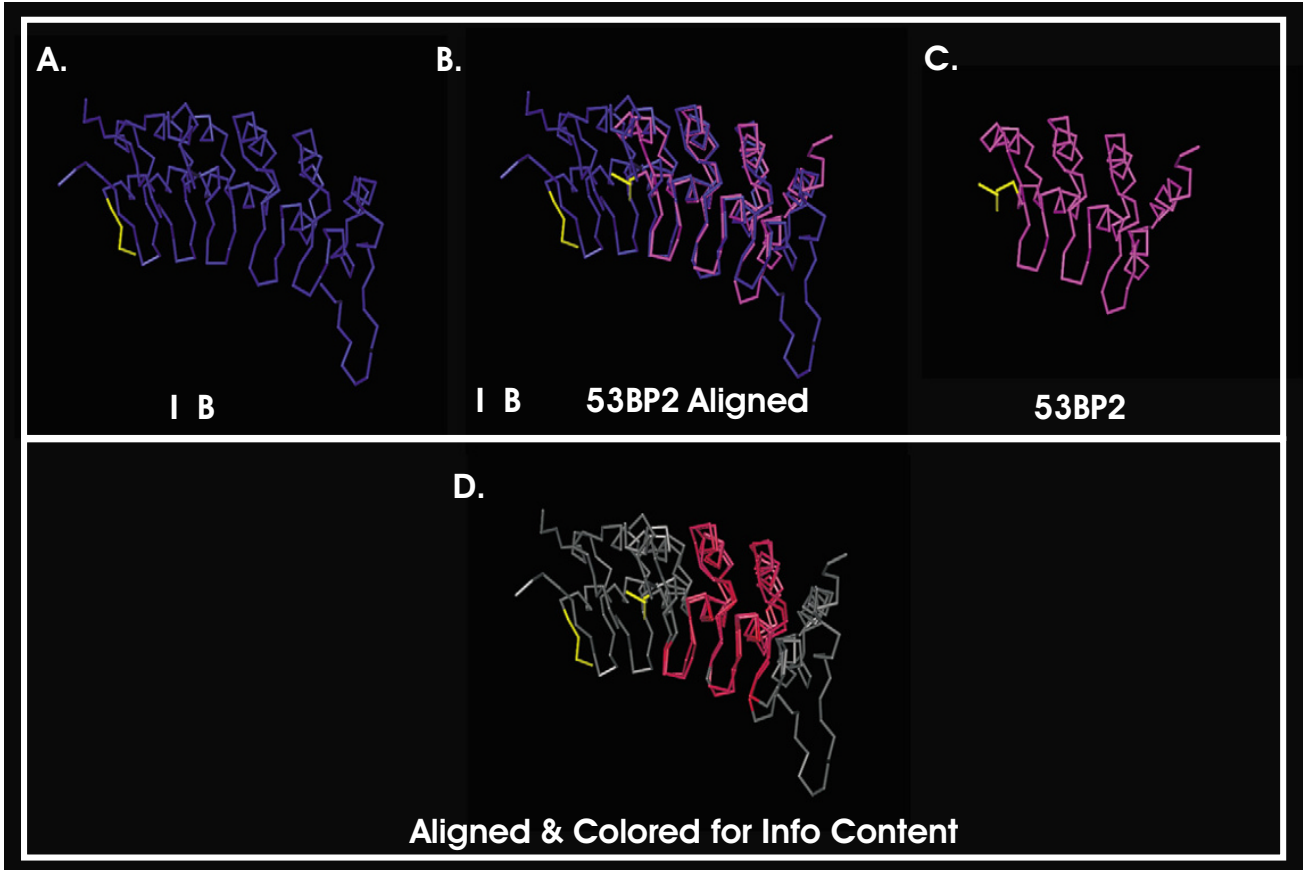

E.

$10 \quad 20 \quad 30 \quad 40 \quad 50 \quad 60$

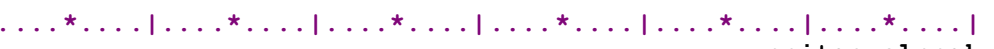

53BP2 B 1 peitgquslppgk 13 IKB $\underline{\bar{D}} 1$ kqql tedgdsflhlaiiheekaltmevirqvkgdlaflnfqnnlqqtplhlavitnqpei 60

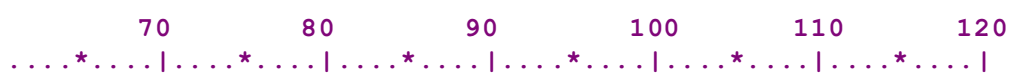

53BP2 B 14 rtnlrktgseriahgmrvkfnplplallldsslegefdlvqriiyevddps lpNDEGITA 73

IKB_D 61 aeallgagcdpelrdfrgntplhlaceqgclasvgvltqscttphlhsilkatNYNGHTC 120

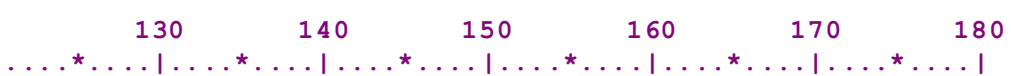

53BP2 B 74 LHNAVCAGHTE IVKFLVQF GVNVNAAD SDGWTPLHCAASCNNVQVCKFLVES GAAVFAM 132 IKB_D- 121 LHLASI HGYLG IVELLVSLGADVNAQEPCNGR TALHLAVDL QNPDLVSLLLKCGADVNRV 180

$$
\begin{gathered}
190 \\
200
\end{gathered} 210 \quad 220 \quad 230 \quad 240
$$

53ВР2 В 133 TYsdmq taadk ceemeegy tqcsqf 1 ygvqekmgimn kgvi yalwdyepqnddelpmkeg 192 IKB D 181 TYqgyspyqltwgrpstriqqqlgqltlenlqmlpesedeesydtesefteftede 236

$$
\begin{gathered}
250 \\
260
\end{gathered} 270 \quad 280
$$

53BP2 B 193 dcmtiihrededeiewwwarlndkegyvprnllglyprikprqrsla 239

IKB_D

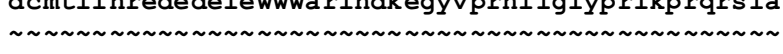

\section{Figure 2}

Alignment of IKB $\alpha$ (PDB ID:IIKN; IIKN_D dI) with p53 binding protein 2 (PDB ID:IYCS; IYCS_B dI). (A) The structure of $I \kappa B \alpha$ (taken from the crystal structure of the $p 50 / p 65$ heterodimer bound to $I \kappa B \alpha$ ); (B) The aligned structures of $I \kappa B \alpha$ and 53BP2; (C) The structure of 53BP2 (taken from the crystal structure of p53 bound to 53BP2); (D) The aligned structure in 2B colored for conservation according to information content as described above; (E) The sequence alignment of IKB $\alpha$ and $53 B P 2$ is depicted using the same coloring scheme as in the structure alignment in 2D. A four amino acid region near the $\mathrm{N}$-termini of each structure is colored yellow as a reference point. 

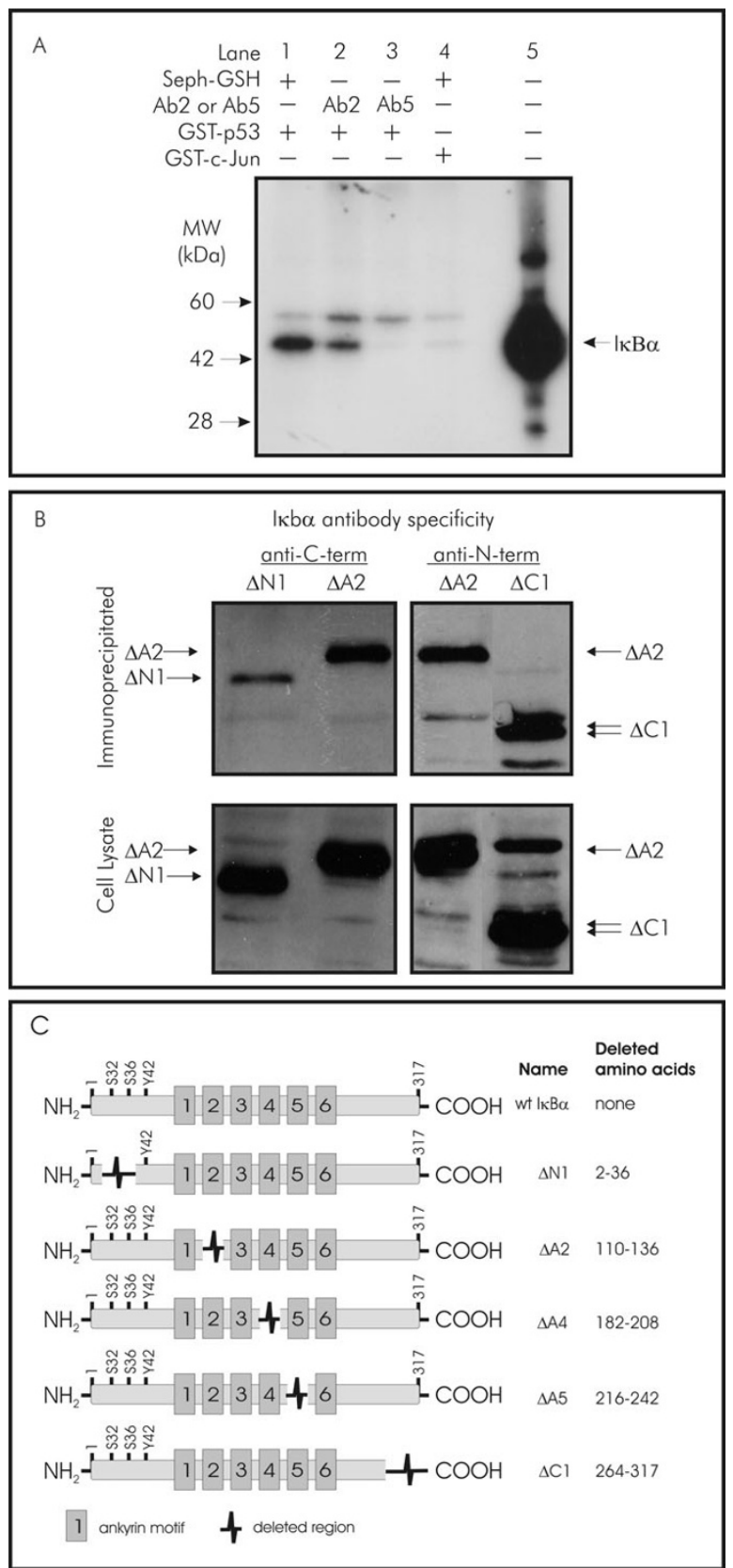

Figure 3

$\mathrm{P} 53$ and IKB $\alpha$ proteins co-precipitate in vitro. A: Purified bacterially produced IKB $\alpha$ protein co-precipitated specifically with $\mathrm{p} 53$.

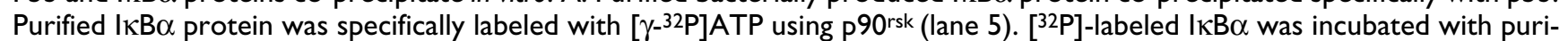
fied p53 (GST-p53, lanes I-3) or a control GST fusion protein (GST-c-Jun, lane 4). P53 was precipitated either by a glutathione binding tag on GST-p53 and glutathione Sepharose beads (Seph-GSH, lane I) or a p53 specific antibody (Ab2, lane 2) and protein A/G Sephadex beads. IKB $\alpha$ protein (position indicated) was not precipitated by $p 53$ specific Ab5 (lane 3) that does not recognize bacterially synthesized $\mathrm{p} 53$ protein, or by incubation with GST-c-Jun and precipitation with glutathione Sepharose beads (lane 4). Proteins were separated by PAGE and detected by autoradiography of [32P]-labeled protein. Electrophoresis of the input I $\kappa \mathrm{B} \alpha$ used in this experiment is also shown in lane 5. B: Relatively less $\Delta \mathrm{NI}$ protein than $\Delta \mathrm{CI}$ IKB $\alpha$ protein co-precipitated with GST-p53 from COS cell lysates. After expression of $I \kappa B \alpha$ in COS cells, whole cell lysates were incubated with bacterially produced purified p53 (GST-p53). P53/ IKB $\alpha$ complexes were then precipitated with glutathione Sepharose beads and analyzed by PAGE/Western blotting. In the left panels, $\Delta \mathrm{NI}$ and $\triangle \mathrm{A} 2$ proteins were detected using a rabbit polyclonal antisera directed at the $\mathrm{C}$-terminus of $\mathrm{I} \mathrm{KB} \alpha$, while in the right panels, $\Delta \mathrm{A} 2$ and $\Delta \mathrm{Cl}$ proteins were detected using a rabbit polyclonal antisera directed at the $\mathrm{N}$-terminus of $I \kappa B \alpha$. C: Structures of wild-type $I \kappa B \alpha$ and mutant constructs used in these studies. 
(unpublished observations), and Ab5 was used as a control for non-specific association between I $\kappa \mathrm{B} \alpha$ and antibody or Protein A/G beads. A c-Jun protein with a glutathione binding protein tag (GST-c-Jun) was used as a control for non-specific association between $\mathrm{I} \kappa \mathrm{B} \alpha$ and glutathione beads. As shown, no association between control proteins or antibodies was evident.

\section{Relatively decreased in vitro binding between $I K B \alpha$ and p53 results from deletion of the $\mathbf{N}$-terminus of $I \mathrm{~KB} \alpha$}

Initial experiments conducted with both p53 and $\mathrm{I} \kappa \mathrm{B} \alpha$ made in bacterial cells supported the hypothesis that the p53 protein could bind to I $\kappa \mathrm{B} \alpha$. Post-translational modifications of the proteins when expressed in eukaryotic cells could affect the interactions noted, particularly with respect to relative binding affinities of mutant proteins. Furthermore, bacterially produced protein may differ in conformation to those produced in mammalian hosts. Overexpression of $\mathrm{I} \kappa \mathrm{B} \alpha$ alleles in COS cells was used to confirm that binding to p53 was evident with $\mathrm{I} \kappa \mathrm{B} \alpha$ produced in vivo and also to map the p53 binding to sites within I $\mathrm{K} \mathrm{B} \alpha$. Only some alleles of $\mathrm{I} \kappa \mathrm{B} \alpha$ can be overexpressed in COS cells including I $\mathrm{CB} \alpha$ deleted of $\mathrm{N}$-terminal regulatory sequences, denoted $\Delta \mathrm{N} 1$ (missing amino acids 2-36), $\Delta \mathrm{A} 2$ (missing amino acids 110-136), and $\Delta \mathrm{C} 1$ deleted of the PEST-containing non-ankyrin C-terminus (amino acids 264-317). A schematic of deletion mutants of $\mathrm{I} \kappa \mathrm{B} \alpha$ used is depicted in Figure 3C.

After expression of $\mathrm{I} \kappa \mathrm{B} \alpha$ in $\mathrm{COS}$ cells, whole cell lysates were co-precipitated with bacterially produced purified GST-p53 (Figure 3B). These experiments confirmed that binding between the proteins was not related to production of an aberrant form of the I $\mathrm{KB} \alpha$ protein in bacterial cells since alleles of $\mathrm{I} \kappa \mathrm{B} \alpha$ protein produced in COS cells were enriched by incubation and co-precipitation with GST-p53. In representative experiments shown, relatively less $\Delta \mathrm{N} 1$ protein protein co-precipitated with GST-p53 from COS cell lysates as compared to the proportions of $\Delta \mathrm{A} 2$ or $\Delta \mathrm{C} 1 \mathrm{I} \kappa \mathrm{B} \alpha$ proteins associating with p53 suggesting that binding between the proteins at least in part required an intact $\mathrm{N}$-terminal region of I $\kappa \mathrm{B} \alpha$. Relative co-precipitation of the C-terminally deleted form of IкB $\alpha$ was comparable to that of wild-type protein (wild-type data not shown), suggesting that the amino acids 264-317 of IкB $\alpha$ was not important for binding to p53.

\section{The binding between I $K B \alpha$ and $p 53$ is disrupted by an antibody to the DNA-binding region of $p 53$}

Experiments detailed above confirmed that a specific binding association occurs between $\mathrm{I} \kappa \mathrm{B} \alpha$ and $\mathrm{p} 53$ in vitro. Further experiments were designed to approximate the region on $\mathrm{p} 53$ responsible for $\mathrm{I} \kappa \mathrm{B} \alpha \mathrm{binding}$ by use of epitope-specific monoclonal antibodies. Glutathionesepharose beads $(G)$ were used to precipitate p53 (Figure
$4 \mathrm{~A}$, lane 1 , and $4 \mathrm{~B}$, lanes 1 and 5) and were found to coprecipitate I $\kappa \mathrm{B} \alpha$. A monoclonal antibody directed at amino acids 46-55 in the amino terminus of p53 (Ab2) recognized purified bacterially produced p53 (4B, lanes 2 and 6 ) and also co-precipitated $\mathrm{I} \kappa \mathrm{B} \alpha$ with p53 (4A, lane 2 ). In contrast, a different p53-specific monoclonal antibody directed at amino acids 212-217 within the DNA binding core of p53 (Ab3), while able to recognize and precipitate bacterially produced $\mathrm{p} 53$ protein $(4 \mathrm{~B}$, lanes 3 and 7 ), did not co-precipitate IאBa (4A, lane 4). These observations suggested that the binding site between purified $\mathrm{I} \kappa \mathrm{B} \alpha$ and $\mathrm{p} 53$ in part coincided with the Ab3 epitope, a region which is within the p53 DNA binding core. Alternatively, the antibody could hinder or disrupt I $\kappa \mathrm{B} \alpha$ binding to regions near the recognized. epitope or alter the structure of p53 into a conformation unfavorable for $\mathrm{I} \kappa \mathrm{B} \alpha$ binding.

\section{Overexpression of wild-type I $\mathrm{kB} \alpha$ modulates $\mathrm{p} 53$ dependent transcription of a synthetic p53 reporter gene in vivo}

In vitro studies supported the hypothesis that a direct physical association between p53 and I $\mathrm{IB} \alpha$ can occur but they did not provide evidence that such interactions occur in vivo. We hypothesized that transient overexpression of $\mathrm{I} \kappa \mathrm{B} \alpha$ in cells with co-transfected transcriptionally active p53 might reveal effects of I $\kappa \mathrm{B} \alpha$ upon p53 mediated transcription. Using forced overexpression of both proteins from identical viral CMV promoter elements rather than endogenous promoters would eliminate confounding transcriptional effects of $\mathrm{I} \kappa \mathrm{B} \alpha$ upon transcription of p53 or vice versa. Any effect of NF- $\mathrm{\kappa B}$ upon $\mathrm{CMV}$ would be normalized as well.

Akata cells were used because these B-lymphoblastoid cells are known to lack endogenous p53. Neither the wildtype nor a mutant protein is expressed that could complicate interpretation of results. P53 transiently transfected into these cells using dextran sulfate is transcriptionally active. As a control for non-specific effects of transfected plasmid DNA, effects of $I \kappa B \alpha$ expression plasmids were compared to co-transfected plasmid containing an identical CMV promoter element (pCMV). Results shown were also normalized to expression of co-transfected pRL-SV40, a plasmid expressing a second form of luciferase as a control for cell viability and transfection efficiency. We found that wild-type I $\mathrm{KB} \alpha$ was associated with decreased p53dependent transcription of the p53 reporter gene pG(13)PyLuc in Akata cells (Figure 5). Increasing the relative ratio of transfected expression plasmids between $\mathrm{I} \kappa \mathrm{B} \alpha$ and $\mathrm{p} 53$ from 1:1 (equivalent to $200 \mathrm{ng} \mathrm{I} \kappa \mathrm{B} \alpha$ plasmid transfected) to $10: 1$ (equivalent to $2000 \mathrm{ng}$ I $\kappa \mathrm{B} \alpha$ plasmid transfected) demonstrated a dose response effect that varied with different $\mathrm{I} \kappa \mathrm{B} \alpha$ alleles. Immunoblotting for wtp53, $\Delta$ C-p53, and I $\kappa \mathrm{B} \alpha$ alleles show relatively equivalent 


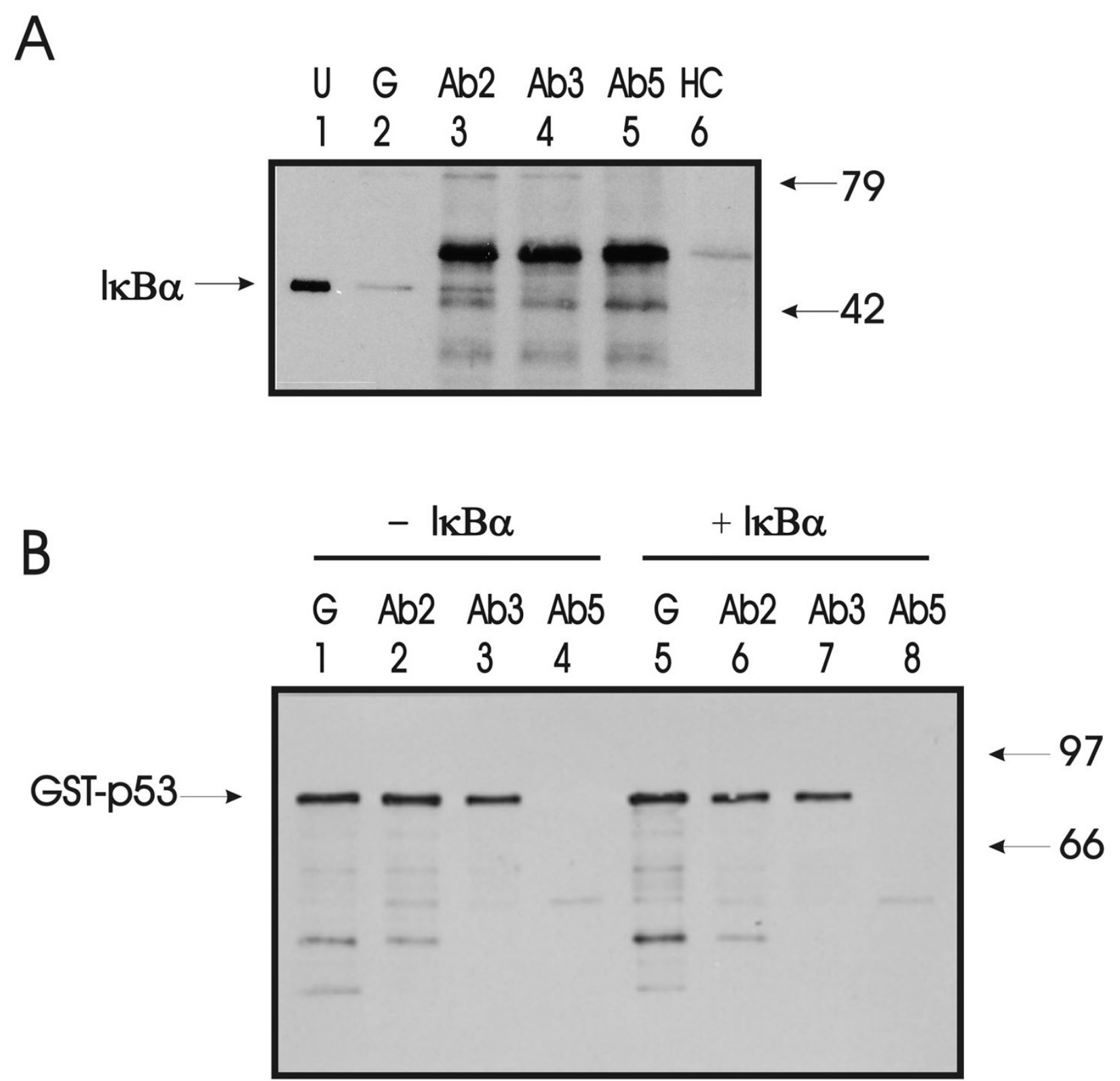

\section{Figure 4}

A monoclonal antibody recognizing an epitope in the DNA binding domain of $p 53(\mathrm{Ab} 3)$ interferes with $I \kappa B \alpha$ binding to $p 53$. Purified p53 with a glutathione binding protein epitope tag (GST-p53) and purified I $\mathrm{B} \alpha$ protein were incubated together in vitro. A. P53 was precipitated either with glutathione Sepharose (denoted G, lane 2) or with p53-specific monoclonal antibodies Ab2 (lane 3), Ab3 (lane 4), or Ab5 (lane 5) and Sephadex protein A/G beads. Precipitated proteins were separated by SDSPAGE and detected by Western blotting with a rabbit polyclonal antiserum directed against the $\mathrm{N}$-terminus of IKB $\alpha$. Mobility of $I \kappa B \alpha$ protein is indicated (lane I). This also represents the total input I $\mathrm{B} \alpha$. Similar quantities of murine immunoglobulin heavy chain ( $\mathrm{HC}$, lane 6) were precipitated by protein A/G beads and served as the negative control. B. GST-p53 was quantitatively precipitated in the absence $(-I \kappa B \alpha)$ or presence $(+I \kappa B \alpha)$ of $I \kappa B \alpha$ by glutathione Sepharose (denoted $G$, lanes I,5), Ab2 (lanes 2,6), and Ab3 (lanes 3,7), but not Ab5 (lanes 4,8), as detected with a rabbit polyclonal p53 antiserum. This blot is essentially identical to that shown in panel A but for the antibody used in the Western blotting step. Since Ab5 did not precipitate GST-p53, it served as a negative control for non-specific association between IKB $\alpha$ protein and either antibody or protein A/G beads. 
A.

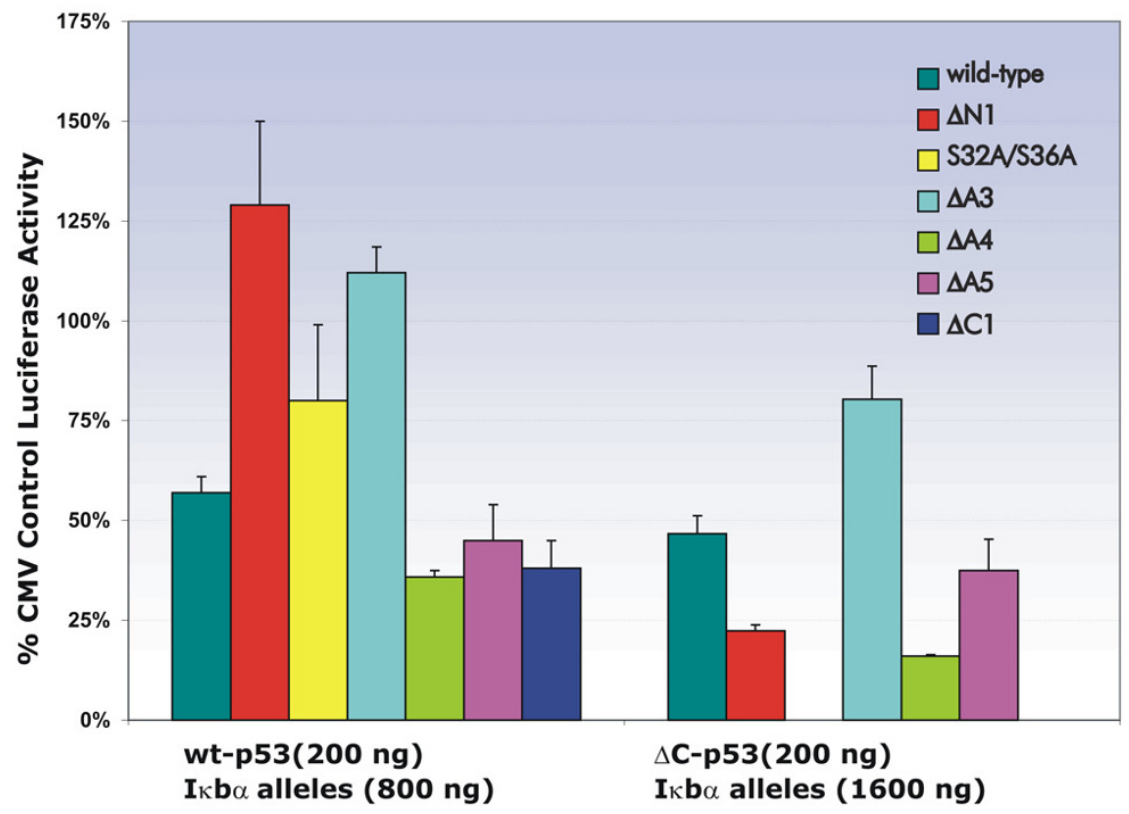

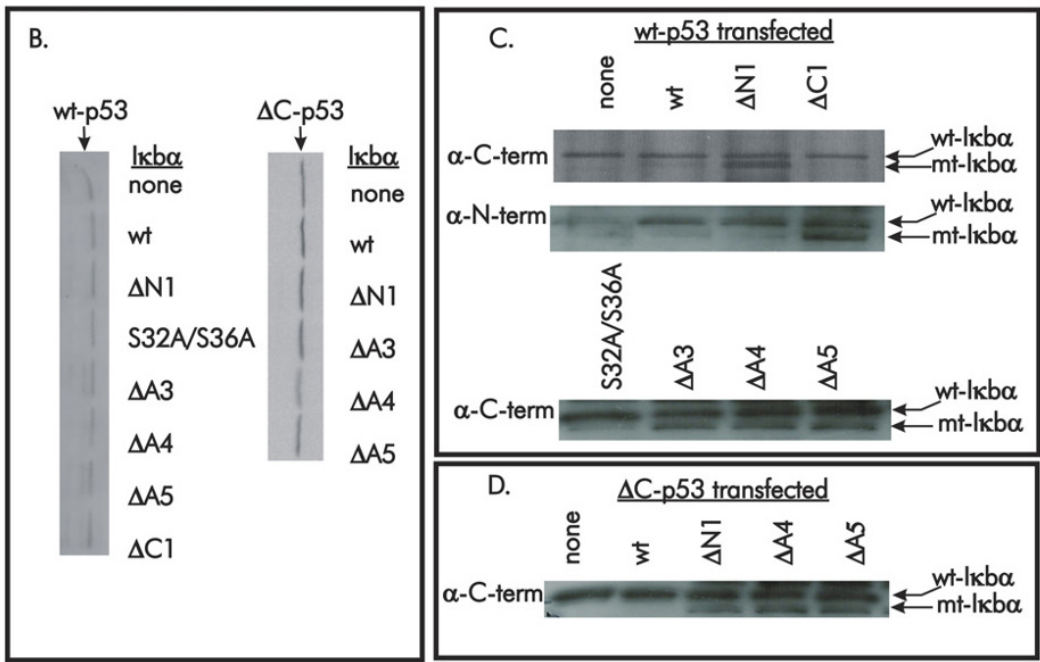

\section{Figure 5}

Transient transfection of $1 \kappa B \alpha$ alleles specifically blocks p53 transcription in EBV-positive Akata cells. A. $200 \mathrm{ng}$ of a p53dependent reporter plasmid encoding I 3 copies of the p53 response element driving a firefly luciferase (pG(I3)Py/Luc) were cotransfected into $2 \times 10^{5}$ cells with I ng of an SV40 promoter driven Renilla luciferase (pRLSV40) and 200 ng of a CMV-promoter driven wild-type p53 cDNA construct (wt-p53, denoted below the x-axis) or a C-terminally deleted transcriptionally active p53 ( $\Delta$ C-p53, denoted below the $\mathrm{x}$-axis). The effect of $800 \mathrm{ng}$ of CMV-promoter driven I $\mathrm{B} \alpha \alpha$ alleles or a control construct that did not contain DNA encoding $I \kappa B \alpha$ (to which all data were normalized) were used to determine the effect of I $\mathrm{B} B \alpha$ on wild-type p53-mediated transcription of pG(13)Py/Luc while $1600 \mathrm{ng}$ of CMV-promoter driven I $\mathrm{KB} \alpha$ alleles (or control) were used in experiments where the $\Delta \mathrm{C}-\mathrm{p} 53$ allele was used. Immunoblotting controls for wt-p53, $\Delta \mathrm{C}-\mathrm{p} 53$ and I $\mathrm{kB} \alpha$ alleles. B: Western blot analysis of wt-p53 and $\Delta \mathrm{C}-\mathrm{p} 53$ in the presence of transfected I $\mathrm{B} B \alpha$ alleles. Extracts were derived from Akata cells as described for Figure 5A. None indicates transfection of empty CMV vector containing no IKB $\alpha$ allele. C: Western blot analysis for $I_{\mathrm{K}} \mathrm{B} \alpha$ in the presence of transfected wt-p53. A subset of extracts were analyzed both with $\mathrm{C}$-term and $\mathrm{N}$-term directed $I \kappa B \alpha$ antibodies. Endogenous $I \kappa B \alpha$ is detected by these methods. $D$ : Western blot analysis of I $B \alpha$ in the presence of $\Delta \mathrm{C}-\mathrm{p} 53 . \Delta \mathrm{A} 3$ was analyzed on a separate gel due to space limitations and showed a band intensity similar to that of $\Delta \mathrm{A} 4$ and $\Delta \mathrm{A} 5$ (data not shown). 
protein levels for these proteins in these extracts (Figure 5B-D).

\section{Allele specific modulation of $p 53$ transcription by I $k B \alpha$ are independent of the effects of the alleles on NF- $\kappa B$ transcription in vivo}

The wild-type IкB $\alpha$ protein is subject to signal-dependent phosphorylation and subsequent degradation leading to release of inhibition of NF- $\kappa B$. Deletion (e.g. as in the $\Delta \mathrm{N}$ allele deleting amino acids 2-36) or mutation of the phosphorylation sites (S32 and S36) in the amino terminus of IкB $\alpha$ leads to a stable mutant that constitutively represses NF- $\kappa B$ transcription. Cotransfection at a 1 to 1 ratio of $\Delta \mathrm{N} 1$ to $\mathrm{p} 53$ expression plasmid (200 ng each of p53 and I $\mathrm{\kappa B} \alpha$ plasmid transfected) had no significant effects upon p53 transcription (data not shown). Increasing the relative ratio of $\Delta \mathrm{N} 1$ expression plasmid to p53 showed that at higher ratios, $\Delta \mathrm{N} 1$ could significantly decrease p53-dependent transcription (Figure 5A, inhibition of the constitutively active $\Delta \mathrm{C}$-p53 is shown at 1600 ng $\Delta \mathrm{N} 1$ plasmid. Similar results were obtained when the ratio of $\Delta \mathrm{N} 1$ to wild-type p53 was increased to $8: 1$, data not shown). However, at the lower ratio of 4:1 shown for the wild-type p53 allele, in Figure 5A, there was little inhibition of transcriptional activity by $\Delta \mathrm{N} 1$. The relatively poor inhibitory activity of $\Delta \mathrm{N} 1$ towards p53 is consistent with its relatively poor binding affinity for p53 as shown in Figure 3B and described above.

The finding that the $\Delta \mathrm{N} 1$ allele is only partially competent to inhibit p53 is consistent with our previous observation that deletion of the N-terminus of IKB $\alpha$ reduced its physical affinity for p53 (Figure 3). While the $\Delta \mathrm{N} 1$ allele is a super-repressor of NF- $\mathrm{KB}$, the $\Delta \mathrm{A} 5$ allele does not repress $\mathrm{NF}-\mathrm{KB}$, and thus this allele could be used to ask whether p53 repression and NF-KB inhibition are separable characteristics of the I $\mathrm{KB} \alpha$ molecule. Remarkably, $\Delta \mathrm{A} 5$, which cannot repress NF- $\mathrm{KB}$ transcription, had very pronounced inhibitory effects upon transcription by p53 (Figure 5A), comparable to that of wild-type.

\section{Mapping of interactions between I $\mathrm{B} B \alpha$ and $p 53$ in vivo to the ankyrin 3 domain of $I \kappa B \alpha$}

Ankyrin regions in $\mathrm{I} \kappa \mathrm{B} \alpha$, shared with other members of the I $\kappa \mathrm{B}$ gene family are the sites of binding to NF- $\mathrm{KB}$ transcription factor family members. Further experiments were performed to define the effects of deletion of additional ankyrin domains of IKB $\alpha$ upon p5 53 transcription in Akata cells. In these experiments, shown in Figure 5, IкB $\alpha$ plasmids were transfected at $800 \mathrm{ng}$ (at a ratio of 4:1 relative to p53 plasmid). Deletion of either the second ( $\triangle \mathrm{A} 2$, amino acids 110-136, not shown) or fourth ankyrin domains ( $\triangle \mathrm{A} 4$, amino acids $182-208)$ had the most potent inhibitory effects upon p53 transcription. Deletion of amino acids $264-317$ in the carboxyl terminus $(\Delta \mathrm{C} 1)$, distal to the $6^{\text {th }}$ ankyrin domian, were similarly inhibitory. This region retains the $6^{\text {th }}$ ankyrin domain but deletes a potentially regulatory acidic PEST region. Deletion of the ankyrin 1 domain of IKB $\alpha$ was not evaluated in this work.

In multiple experiments with wild-type p53, deletion of the ankyrin $3(\Delta \mathrm{A} 3)$ domain of I $\mathrm{KB} \alpha$ (missing amino acids 143-169) resulted in a loss of inhibitory activity towards p53 transcription. Thus $\Delta \mathrm{A} 3$ acts as a null allele for both p53 and NF- $\kappa B$ transcription in vivo, while other ankyrin deletion alleles of I $\mathrm{B} \alpha(\Delta \mathrm{A} 2, \Delta \mathrm{A} 4, \Delta \mathrm{A} 5)$ act as null alleles for NF- $\kappa B$ but gain of function with respect to p53. Thus, our data are consistent with the hypothesis that the ankyrin 3 and $\mathrm{N}$-terminus of I $\mathrm{KB} \alpha$ are cooperatively or independently involved in repressing p53. We cannot, however, rule out an alternative possibility, that the deletion of the ankyrin $3(\triangle \mathrm{A} 3)$ of I $\mathrm{I} B \alpha$ resulted in a protein with high turnover in Akata cells.

\section{Relative effects of alleles of I $\kappa B \alpha$ are conserved with constitutively active $p 53$ and require transcriptionally active $\mathbf{p 5 3}$}

P53 transcription is regulated in part by phosphorylation of the carboxyl terminus of the protein. Phosphorylation induces a conformational change in p53 so that an autoinhibitory region of the carboxyl terminus no longer inhibits DNA binding [73-75]. To determine whether the effects of IKB $\alpha$ upon p53 transcription required the autoinhibitory carboxyl terminus of p53, experiments were repeated with a truncated form of p53 containing the first 353 amino acids (Figure 5A, $\Delta \mathrm{C}$-p53) together with an 8fold excess of IкB $\alpha$ plasmid (1600 ng). As expected, these experiments demonstrated increased p53 transcriptional activity measured as p53 -dependent transcription of pG(13)PY/Luc in Akata cells at the same plasmid concentrations compared to experiments using wild-type p53. Co-transfection of a fixed concentration of a plasmid expressing $\Delta \mathrm{C}$-p53 protein (200 ng), and I $\mathrm{\kappa B} \alpha$ alleles $(1600 \mathrm{ng})$ demonstrated that the carboxyl terminus of p53 was not required for the association between p53dependent transcription and $\mathrm{I} \kappa \mathrm{B} \alpha$ expression. As in experiments with wild-type p53, deletion of the ankyrin 4 $(\triangle \mathrm{A} 4)$ domain of $\mathrm{I} \kappa \mathrm{B} \alpha$ was associated with greater decreases in p53-dependent transcription than other alleles of $I \kappa B \alpha$. A transcriptionally inactive p53 mutated in the $\mathrm{p} 53$ DNA binding core (pC53-CSX3, V193A) gave very low levels of luciferase activity that were not altered by cotransfection of any I $\mathrm{KB} \alpha$ alleles (data not shown). Thus, the effects of IкB $\alpha$ upon p53 transcription in Akata cells were found to be entirely dependent upon the presence of co-transfected transcriptionally active p53 but independent of the carboxyl-terminus regulatory sequences of p53.

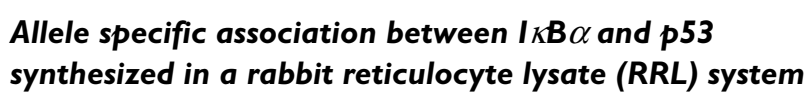


correspond to allele specific modulation of transcription in vivo

Some alleles of $\mathrm{I} \kappa \mathrm{B} \alpha$ including $\Delta \mathrm{A} 3$ and $\Delta \mathrm{A} 4$ were not stable in COS cells (unpublished observations). Therefore, COS cells could not be used to determine the correlation between $\mathrm{I} \kappa \mathrm{B} \alpha$ and $\mathrm{p} 53$ binding in vitro (Figure $2 \mathrm{~B}$ ) and transcriptional effects in Akata cells (Figure 5). Thus, to overcome this technical problem, p53 and $\mathrm{I} \kappa \mathrm{B} \alpha$ proteins were both separately synthesized in a rabbit reticulocyte lysate system (Figure 6 ). I $\mathrm{\kappa} \mathrm{B} \alpha$ synthesized in the reticulocyte lysate system is functionally active in its effects upon NF- $\kappa \mathrm{B}$ transcription factors and ubiquitin-dependent degradation. Likewise, but in contrast to bacterially synthesized p53, p53 synthesized in RRL system is functionally active as a site-specific DNA-binding protein and like I $\mathrm{B} \alpha$ is degraded in vitro by a ubiquitin-dependent pathway. Experiments were performed to determine whether RRL produced p53 that could interact with $\mathrm{I} \kappa \mathrm{B} \alpha$ alleles likewise translated in vitro in RRL.

Coupled transcription/translation of a plasmid encoding wild-type p53 in RRL (lane 1, Figure 6B) resulted in several template-specific products that could be precipitated from lysates with p53-specific monoclonal antibodies (lanes 2 and 3, Figure 6B). These products appeared to be a mixture of full length and less-than full-length p53 proteins resulting from internal initiation sites in the $\mathrm{p} 53$ template. Negative control precipitation with IgG2A immunoglobulin (lane 4) or protein G/A beads (lane 5) resulted in undetectable levels of p53 recovery.

I $\mathrm{B} \alpha$ was precipitated with a polyclonal antiserum directed at the IкB $\alpha$ C-terminus in the absence (p53-) or presence of $\mathrm{p} 53(\mathrm{p} 53+)$ protein after both proteins were synthesized in the reticulocyte lysate system (Figure 6A). Deletion of the carboxyl terminus of I $\kappa \mathrm{B} \alpha$ did not interfere with binding between GST-p53 and I $\mathrm{KB} \alpha$ synthesized in COS cells (Figure 2), suggesting that binding of antibody directed at the I $\mathrm{KB} \alpha$ carboxyl terminus would not interfere with binding between p53 and $\mathrm{I} \kappa \mathrm{B} \alpha$. Visual inspection and gel densitometry of these co-precipitation experiments confirmed a specific association between wild-type $\mathrm{I} \kappa \mathrm{B} \alpha$ and $\mathrm{p} 53$. The association of $\triangle \mathrm{A} 3 \mathrm{I} \mathrm{I} \mathrm{B} \alpha$ allele to p53 was significantly reduced (Figure 6A, p53+, lane 3 ) as determined by gel densitometry (Figure 6D, p < $0.05)$ relative to the association between the wild-type $\mathrm{I} \kappa \mathrm{B} \alpha, \Delta \mathrm{A} 4$, and $\Delta \mathrm{A} 5$ alleles of $\mathrm{I} \kappa \mathrm{B} \alpha$ to $\mathrm{p} 53$. Gel densitometry was not sensitive enough to determine whether small differences in the binding of other $\mathrm{I} \kappa \mathrm{B} \alpha$ alleles to $\mathrm{p} 53$ were significant. In the absence of labeled $\mathrm{I} \kappa \mathrm{B} \alpha$, bands corresponding to p53 were still evident (5A, lane 1, p53+) suggesting either non-specific binding or co-precipitation with endogenous unlabeled $I \kappa \mathrm{B} \alpha$. There are small quantities of immuno-detectable I $\kappa \mathrm{B} \alpha$ in certain preparations of RRL (L. Ghoda, unpublished observations). Similar results were obtained in experiments in which an antibody against p53 (Ab2) were used to co-precipitate p53 and $\mathrm{I} \kappa \mathrm{B} \alpha$ alleles (unpublished observations). Binding was also evident between $I \kappa B \alpha$ and p53-related proteins smaller in size than full-length p53 although these interactions could not be reliably quantitated due to variable co-migrating protein species in the relevant portions of the gel.

\section{In vivo binding of $\triangle A \mathbf{A 5}-\mathrm{I} K \mathbf{B} \alpha$ to wild-type $\mathbf{p 5 3}$}

The melanoma cell line A2085 expressing endogenous wild-type p53 was stably transfected with the hemagluttinin (HA)-tagged $\Delta \mathrm{A} 5$ allele of $\mathrm{I} \kappa \mathrm{B} \alpha[76]$. The $\Delta \mathrm{A} 5$ allele was chosen because it has no effect on NF- $\kappa \mathrm{B}$ activity but is one of the more potent alleles of $I \kappa B \alpha$ in modulating p53-dependent transcription. Several independent stable clones as well as pooled transfectants were expanded and used for experiments for which results of the pooled transfectants (DA5) are shown here (Figure 7). Results were qualitatively similar with pooled $v s$ cells expanded from single colonies. Pooled transformants resulting from antibiotic selection of vector transfected cells were used as controls (Con). Association of $\Delta \mathrm{A} 5-\mathrm{I} \kappa \mathrm{B} \alpha$ with $\mathrm{p} 53$ was evident when UV-irradiated cell extracts were immunoprecipated using anti-p53 antibody and the immunoprecipitates probed with anti-I $\kappa \mathrm{B} \alpha$ antibody (top panel). Likewise, association between transfected $\mathrm{I} \kappa \mathrm{B} \alpha$ and $\mathrm{p} 53$ are evident when immunoprecipitates generated using anti-HA were probed with anti-p53 (bottom row). Immunoprecipitation with normal rabbit serum (ns) precipitated little or no $\mathrm{I} \kappa \mathrm{B} \alpha$ or $\mathrm{p} 53$. Association between endogenous wild-type $\mathrm{I} \kappa \mathrm{B} \alpha$ and p53 are also evident as seen by the upper band detectable with anti-IкB $\alpha$ western blotting in Con and DA5 lanes when extracts are precipitated with anti-p53. When extracts of irradiated cells are immunoprecipitated with anti-HA, and immunoblotted with anti-I $\kappa \mathrm{B} \alpha$, Both endogenous and $\Delta \mathrm{A} 5$ are evident. This is likely due to the precipitation of wt- I $\mathrm{BB} \alpha$ with the $\mathrm{p} 53 / \Delta \mathrm{A} 5-\mathrm{I} \kappa \mathrm{B} \alpha$ complex since $\mathrm{p} 53$ exists as a tetramer.

\section{Discussion}

In this work we determined that $\mathrm{I} \kappa \mathrm{B} \alpha$ and $\mathrm{p} 53$ bind in vitro through a specific interaction in part involving the DNA binding region of p53, or a region proximal to it, and the amino terminus of I $\kappa \mathrm{B} \alpha$ independently or cooperatively with the ankyrin 3 domain of I $\mathrm{KB} \alpha$. A physical interaction between $\mathrm{p} 53$ and $\mathrm{I} \kappa \mathrm{B} \alpha$ has been noted by two other groups $[68,69]$. Generally, our data corroborate these previously reported interactions and provide further evidence for direct transcriptional modulation of p53 by $\mathrm{I} \kappa \mathrm{B} \alpha$. There are some notable differences in our observations from that of others, in particular, the binding site on $\mathrm{I} \kappa \mathrm{B} \alpha$ was reported as existing in the non-ankyrin C-terminus by Chang [68] in an yeast two-hybrid system using a 

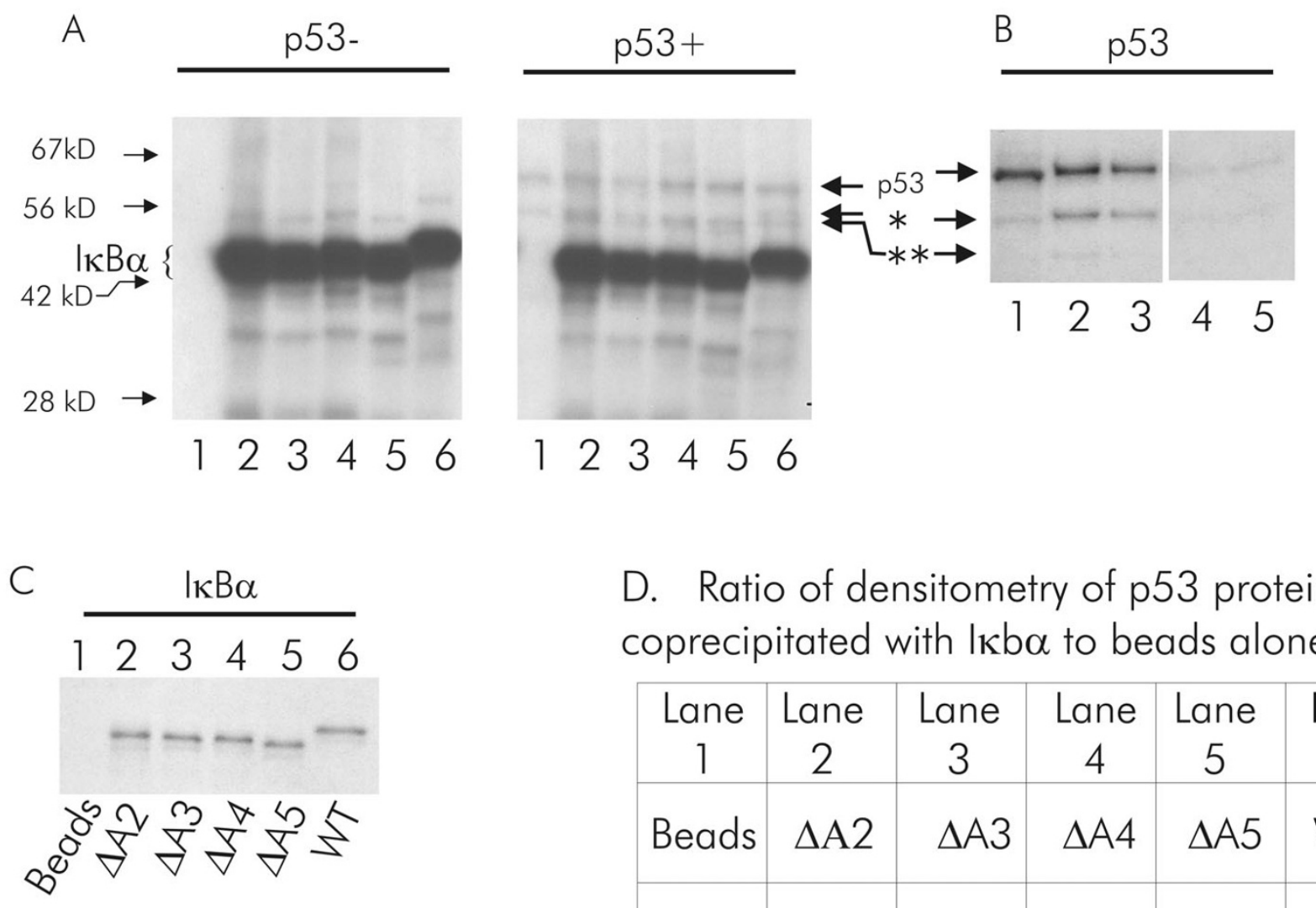

D. Ratio of densitometry of $\mathrm{p} 53$ protein
coprecipitated with Ikba to beads alone.

\begin{tabular}{|c|c|c|c|c|c|}
\hline $\begin{array}{c}\text { Lane } \\
1\end{array}$ & $\begin{array}{c}\text { Lane } \\
2\end{array}$ & $\begin{array}{c}\text { Lane } \\
3\end{array}$ & $\begin{array}{c}\text { Lane } \\
4\end{array}$ & $\begin{array}{c}\text { Lane } \\
5\end{array}$ & $\begin{array}{c}\text { Lane } \\
6\end{array}$ \\
\hline Beads & $\Delta \mathrm{A} 2$ & $\Delta \mathrm{A} 3$ & $\Delta \mathrm{A} 4$ & $\Delta \mathrm{A} 5$ & $\mathrm{WT}$ \\
\hline 1.00 & - & 1.34 & 2.02 & 2.13 & 1.85 \\
\hline
\end{tabular}

\section{Figure 6}

Rabbit reticulocyte lysate ( $R R L)$ produced $\mathrm{p} 53$ and $I \kappa B \alpha$ proteins interact in vitro. $A$. Wild-type I $\mathrm{B} \alpha$ and mutant proteins were synthesized in rabbit reticulocyte lysates (lane I, RRL no RNA; lane 2, $\Delta \mathrm{A} 2$; lane 3, $\Delta \mathrm{A} 3$; lane 4, $\Delta \mathrm{A} 4$; lane $5, \Delta \mathrm{A} 5$; and lane 6, wild-type) and precipitated with a rabbit polyclonal antiserum against the C-terminus of I $\mathrm{B} \alpha$ using protein $\mathrm{A} / \mathrm{G}$ sephadex beads either in the absence ( $p 53-)$ or in the presence $(p 53+)$ of RRL synthesized, [35S]-labeled, p53. Equal volumes of RRL were used in all cases. For $\mathrm{p} 53$ - reactions, RRL programmed with empty vector was incubated with [ $\left.{ }^{35} \mathrm{~S}\right]$-labeled methionine. A control reticulocyte lysate without I $\mathrm{KB} \alpha$ protein template (lane I) was included in these experiments. $\Delta \mathrm{A} 2$ (lane 2 ), $\Delta \mathrm{A} 3$ (lane 3 ), $\Delta \mathrm{A} 4$ (lane 4) $\Delta \mathrm{A} 5$ (lane 5) and wild-type (lane 6) I $\mathrm{KB} \alpha$ proteins were co-incubated with p53, precipitated and analzyed by SDSPAGE followed by radiography. B. Wild-type $\mathrm{p} 53$ protein translated in RRL (lane I) produced both putative full-length $\mathrm{p} 53$ protein (denoted p53, mobility approximately $55 \mathrm{kD}$ ) and also at least two less-than-full length translation products (denoted $*$ and **; lanes 1-3). Putative full-length and less-than full-length p53 translation products were precipitated by p53-specific monoclonal antibodies and protein A/G sephadex beads (lane 2, Abl recognizing the carboxyl terminus of p53; lane 3, Ab2 recognizing the amino terminus of $\mathrm{p} 53$ ). Less-than full-length proteins were more readily precipitated by Abl than Ab2. Control precipitation with IgG2A immunoglobulin (lane 4) or protein G/A beads (lane 5) did not precipitate $p 53$. C. IKB $\alpha$ proteins were precipitated in similar quantities by $I \kappa B \alpha$ antiserum. A shorter exposure of the gel than in panel $A$ is shown. $D$. Densitometry of $\mathrm{p} 53$ protein precipitated in association with various $\mathrm{I} \kappa \mathrm{B} \alpha$ alleles. Data shows significant precipitation of $\mathrm{p} 53$ with $\Delta \mathrm{A} 4, \Delta \mathrm{A} 5$ and wild-type, expressed as a ratio of label precipitating with $I \kappa \mathrm{B} \alpha$ allele to beads alone. Data was calculated by first normalizing to the background in each lane followed by calculating the ratio of label precipitating with I $\mathrm{K} \alpha$ to a corresponding area in the beads alone lane.

deletion construct missing amino acids 244-317. This construct in fact deletes the $6^{\text {th }}$ ankyrin domain of $\mathrm{I} \kappa \mathrm{B} \alpha$, located at amino acids 244 - 263, retained in our C-termi- nal deletion construct $(\Delta 264-317)$ which also retains p53 binding and regulation. When the data are taken in toto, it can be inferred that in fact the $6^{\text {th }}$ ankyrin domain, 


\section{Immunoprecipitating $\mathrm{Ab}$}

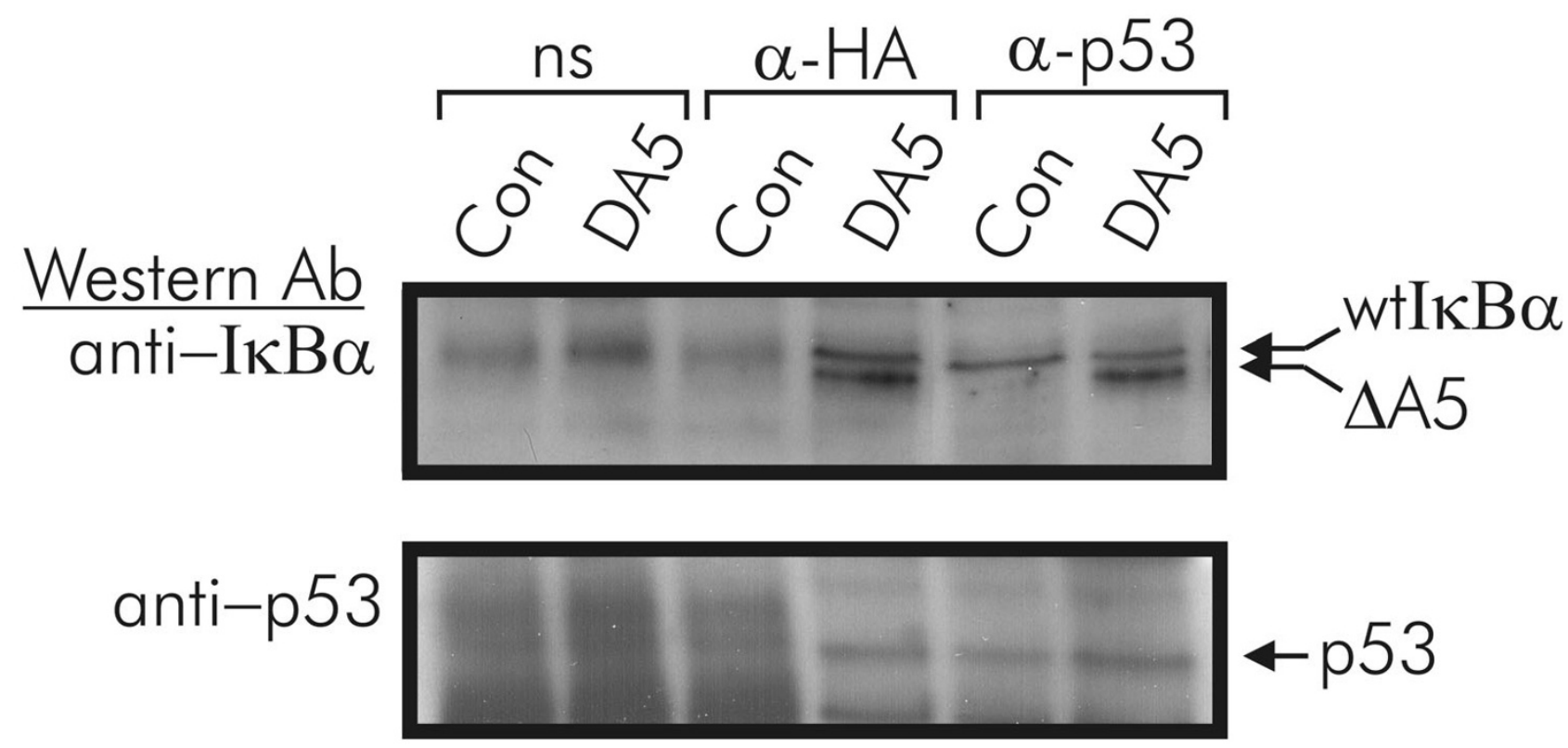

Figure 7

P53 associates with $\triangle \mathrm{A} 5$-I $\kappa \mathrm{B} \alpha$ in UV-irradiated melanoma cells. A2085 cells stably transfected with the parent vector (Con) or $\triangle \mathrm{A} 5$-I $\mathrm{B} \alpha$ allele (DA5) were irradiated for 30" with UVB and harvested 4 hrs later. The extracts were subjected to immunoprecipitation with non specific rabbit serum (ns), polyclonal rabbit anti-HA antibody $(\alpha-H A)$, or mouse monoclonal anti-p53 Ab2 antibody $(\alpha-p 53)$ and probed by western analysis with mouse anti-IKB $\alpha$ antibody directed at the $C$-terminus of IKB $\alpha$ (top panel) or the Ab3 anti-p53 monoclonal antibody (bottom panel). Experiments were performed on stably transfected, pooled transfectants of controls (Con) or $\triangle \mathrm{A} 5-\mathrm{I} \kappa \mathrm{B} \alpha$ (DA5).

retained in our construct but deleted in Chang's, may in fact contain another p53 contact point, the loss of which were observed by Chang but not by us.

We also found that deletion of the ankyrin 2, 4, or 5 domains of $\mathrm{I} \kappa \mathrm{B} \alpha$ increased the inhibitory effect of $\mathrm{I} \kappa \mathrm{B} \alpha$ on p53-dependent transcription in Akata cells. We speculate that the compacting of the structure by elimination of an ankyrin domain may promote better binding of the protein to $\mathrm{p} 53$ as it may convert I $\mathrm{B} \mathrm{B} \alpha$ to a structure closer in size to that of 53BP2 which only contains four ankyrins. Mutations in the ankyrin regions of $\mathrm{I} \kappa \mathrm{B} \alpha$ have been characterized regarding their effects upon NF- $\kappa$ mediated transcription as well as nuclear translocation, with most deletions of ankyrins including deletion of ankyrin 5 leading to a null phenotype (confirmed in part in this work in Akata cells) with respect to NF- $\kappa B$ transcription. Nevertheless, over-expression of $\Delta \mathrm{A} 5-\mathrm{I} \kappa \mathrm{B} \alpha$ was more effective than wild-type at decreasing p53 transcrip- tion at all but the lowest concentrations examined. Thus, it was evident that over-expression of some alleles of $\mathrm{I} \kappa \mathrm{B} \alpha$ could influence p53 transcription independently of their effects upon transcription by NF- $\mathrm{BB}$. Deletion of the ankyrin 3 region of $\mathrm{I} \kappa \mathrm{B} \alpha$ eliminated detectable interactions between I $\mathrm{K} \mathrm{B} \alpha$ and $\mathrm{p} 53$ in vivo and in vitro suggesting a critical role of the ankyrin 3 region in a specific in vivo interaction with $\mathrm{p} 53$. The combined results obtained using bacterially produced $\mathrm{I} \kappa \mathrm{B} \alpha$ and $\mathrm{p} 53$ (Figure 2) as well as RRL produced proteins (Figure 6 ) suggest a correlation between in vitro co-precipitation in at least one of the systems and in vivo p53 inhibitory activity. These observations argue for a mechanism involving direct binding of I $\kappa \mathrm{B} \alpha$ to p53 in the inhibition of p53 transcriptional activity.

Our interpretation of these observations is that binding between $\mathrm{I} \kappa \mathrm{B} \alpha$ and $\mathrm{p} 53$ occurs primarily between the p53 DNA-binding core or a region proximal to it, and the 


\begin{tabular}{|c|c|c|c|c|c|c|c|c|c|c|c|}
\hline & A. & NA & bind & ing $s$ & & & & & & & \\
\hline p53 & $\mathrm{R}$ & $R$ & $R$ & $\mathrm{R}$ & C & $\begin{array}{l}\text { A } \\
T\end{array}$ & $\begin{array}{l}\mathrm{T} \\
\mathrm{A}\end{array}$ & G & Y & Y & Y \\
\hline consensus & & G & G & $G$ & X & $\begin{array}{l}\text { A } \\
T\end{array}$ & $\mathrm{~T}$ & X & Y & C & C \\
\hline proto-p53/NF-кB & & $R$ & $R$ & $R$ & $\begin{array}{l}C \\
R\end{array}$ & $\mathrm{~N}$ & $\mathrm{~N}$ & $\begin{array}{l}G \\
Y\end{array}$ & Y & Y & Y \\
\hline$N F-\kappa B$ & & G & $G$ & $G$ & $R$ & $\mathrm{~N}$ & N & Y & Y & C & C \\
\hline
\end{tabular}

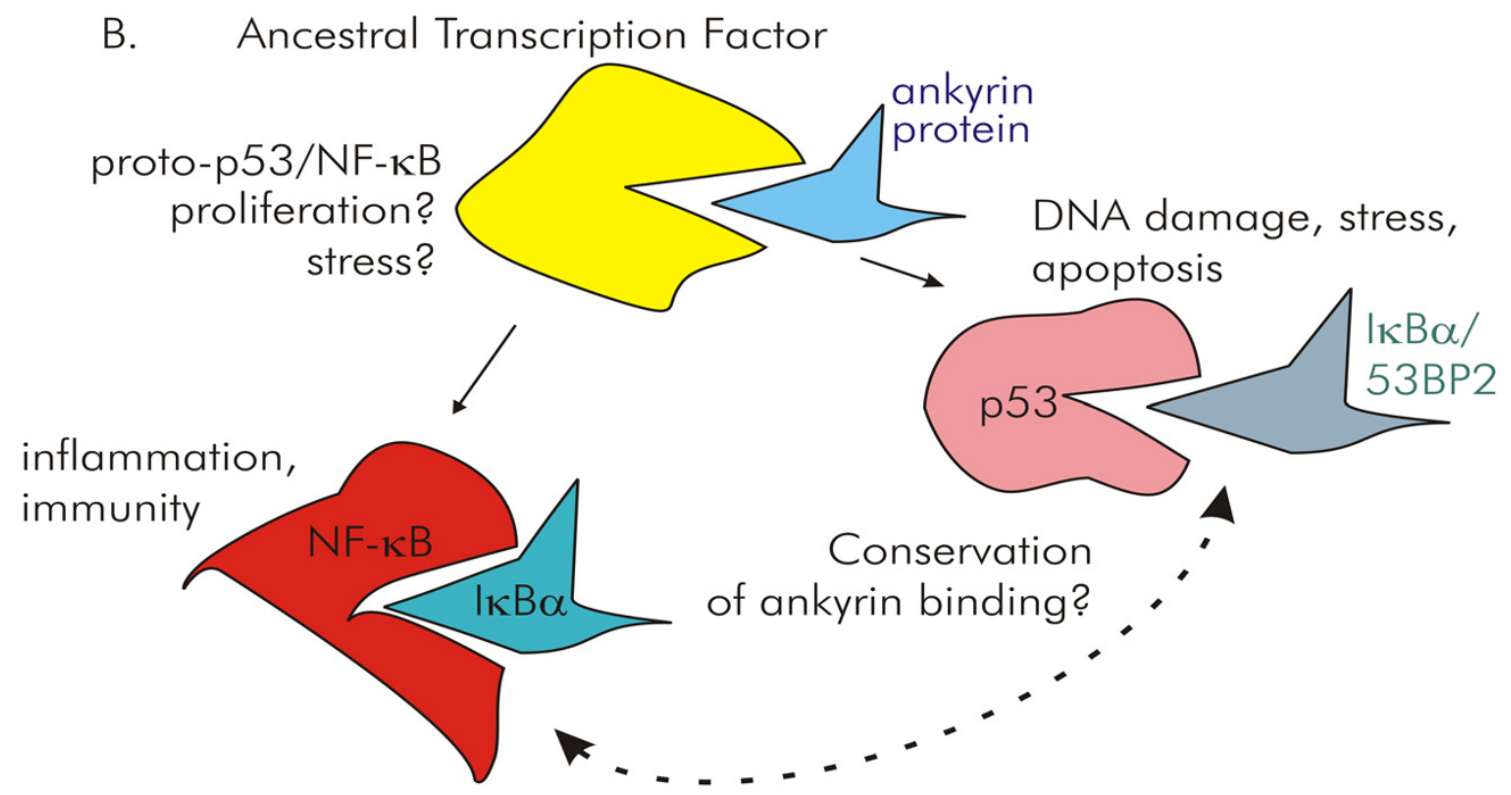

C. Alignment of ankyrin-like domains

\begin{tabular}{|c|c|c|c|c|c|c|c|c|c|c|c|c|c|c|c|c|c|c|c|c|c|c|c|}
\hline$I_{\kappa} B \alpha$ & L & A & V & I & $\mathrm{T}$ & $\mathrm{N}$ & $Q$ & $P$ & G & 1 & A & $\mathrm{E}$ & A & $\mathrm{L}$ & $\mathrm{L}$ & G & A & G & C & D & $P$ & & \\
\hline BZ & $A$ & $A$ & A & K & $S$ & $S$ & $\mathrm{E}$ & $\mathrm{N}$ & $D$ & $R$ & 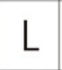 & $R$ & & $\mathrm{~L}$ & L & K & $D$ & $\mathrm{~N}$ & $C$ & - & $P$ & S & \\
\hline & L & A & V & 1 & $\mathrm{~T}$ & K & $Q$ & $\mathrm{~F}$ & D & $\mathrm{V}$ & D & E & & & 1 & 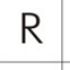 & $\Delta$ & G & A & D & L & & \\
\hline , & L & A & $A$ & L & $\mathrm{T}$ & & $Q$ & $P$ & $\mathrm{~N}$ & 1 & IVI & $R$ & 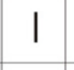 & 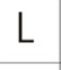 & L & & A & G & A & $E$ & $P$ & $\mathrm{~T}$ & V \\
\hline Unc & I & A & A & K & $K$ & & & $M$ & $E$ & 1 & A & $S$ & & & L & $Q$ & $\mathrm{~F}$ & $\mathrm{~K}$ & $A$ & D & $P 1$ & $\mathrm{~N}$ & $\Delta$ \\
\hline
\end{tabular}

\section{Figure 8}

A model for molecular evolution of $\mathrm{p} 53$ and NF- $\mathrm{KB}$ from a common ancestral transcription factor, proto-p $53 / \mathrm{NF}-\kappa \mathrm{K}$. A. P53 (first row) and NF-KB (fourth row) DNA binding sites share eight out of ten nucleotides as shown by the sequence depicted in the second row (consensus). $\mathrm{R}$ represents purine, $\mathrm{A}$ or $\mathrm{G}$; $\mathrm{Y}$ represents pyrimidine, $\mathrm{C}$ or $\mathrm{T}$. The red $\mathrm{X}$ denotes nucleotides where there is no match. The predicted DNA binding site sequence of the ancestral proto-p53/NF- $\mathrm{kB}$ is shown in the third row. B. An ancestral transcription factor proto- $553 / \mathrm{NF}-\mathrm{KB}$, also regulated by an ankyrin protein, with a DNA binding site shown in A, above, could have been the precursor to both $\mathrm{p} 53$ and NF- $\mathrm{KB}$. C. An ankyrin-like region in EBV protein BZLF-I (ZEBRA) is shown in alignment with ankyrin motifs in $I \kappa B \alpha, N F-\kappa B P 50$, as well as invertebrate ankyrin like regulatory repeats from Drosophila Cactus and C. elegans Unc22. 
ankyrin 3 and $\mathrm{N}$-terminal regions of I $\mathrm{KB} \alpha$. Binding results in decreased p53-dependent transcription when both I $\mathrm{B} \alpha$ and $\mathrm{p} 53$ are overexpressed in vivo. These results are consistent with those published by Zhou, et al. [69] where induction of p53 regulatable genes such as p21 and $\mathrm{Mdm} 2$ in response to doxorubicin was abrogated by expression of a degradation-resistant form of I $\mathrm{I} B \alpha$. These interactions are strikingly similar to the known interac-

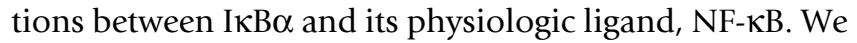
suggest that these interactions are a result of a conserved relationship, i.e., that of a common descent, of p65 and p53 from a primordial transcription factor which we term proto p53/NF- $\mathrm{kB}$ (Figure 8B). Not only do the two transcription factors bind ankyrin proteins but both NF- $\mathrm{KB}$ and p53 have similar DNA binding sites (Figure 8A). Furthermore, both factors bind a viral protein encoded by the EBV BZLF-1 open reading frame (also known as ZEBRA) and can transcription can be modulated by this viral protein when overexpressed in lymphoblastoid cell lines $[64,77]$. As shown in Figure 8C, we found that a cryptic ankyrin like region is present in the dimerization region of BZLF-1, coincident with the region required for binding to both p65 and p53. With the exception of ankyrin domains, BZLF-1 and I $\kappa \mathrm{B} \alpha$ are otherwise not similar in sequence, structure, or function.

Thus, ankyrin repeat domains appear to be key points of interaction between diverse proteins in the NF- $\mathrm{KB}$ and p53 superfamilies. A similar conclusion is suggested by the crystal structure of a complex between p53 and 53BP2 [28]. 53BP2 is a 1002 amino acid protein containing four ankyrin repeats that has been found to be a fragment of an even larger protein known as ASPP2. Residues TYSD located in the $4^{\text {th }}$ ankyrin repeat of 53BP2/ASPP2 (Figure 2E, 133 TYsd) binds to the L2 loop of p53 immediately after the zinc ligand site in p53, while the non-ankyrin, $\mathrm{SH} 3$ domain of 53BP2 also contribute to the binding interactions. These four residues in 53BP2/ASPP2 are exactly aligned with an equivalent block in the sixth ankyrin repeat of IKB $\alpha$ (Figure 2E, 181 TYqq). It is interesting to note that this corresponds to the $6^{\text {th }}$ ankyrin domain predicted to be a contact point for p53 as outlined above. Paradoxically, 53BP2/ASPP2 is exclusively cytoplasmic thus it may only inhibit and sequester p53 in the cytoplasm. IкB $\alpha$ thus may fall into a paradigm of endogenous and viral p53 regulatory proteins where ankyrin and non-ankyrin domains contribute to p53 binding and transcriptional modulation. Other ankyrin proteins that bind to either NF- $\mathrm{KB}$ or p53 could also bind and potentially modulate each other.

\section{Conclusion}

In conclusion, modulation of p53 transcription by IкB $\alpha$ and related host and viral proteins could play a role in the regulation of p53-dependent apoptosis in vivo. Both p53 and I $\mathrm{B} B \alpha$ are members of multi-gene families, and both protein families regulate apoptosis. Previously, a cooperative relationship between p53-dependent apoptosis and NF- $\kappa B$ activation had been reported [59]. Our observations may represent the converse of this situation where

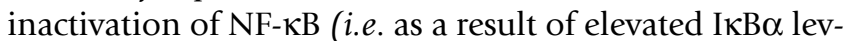
els) results in inhibition of p53 transcriptional activity. Alternatively, a situation where accumulation of I $\mathrm{I} B \alpha$ free of NF- $\mathrm{KB}$, as a result of phosphorylation of p 65 by RSK1

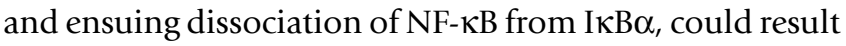
in the regulation of p53 by I $\mathrm{\kappa B} \alpha$ [78]. Another setting where our observations may play a significant physiological role is during herpesvirus infection. The Epstein-Barr nuclear antigen (EBNA1) contains a region enriched in gly-ala repeats, and this repeat sequence inhibits the $26 \mathrm{~S}$ proteasome leading to inhibition of peptide presentation by the MHC Class I restricted pathway [79]. EBNA1 is expressed during viral latency, a condition where it is beneficial for the virus to inhibit apoptosis. Proteasome inhibition will lead to inhibition of all cellular protein degradation and the impact would be the greatest on those proteins with extremely short half-lives such as p53

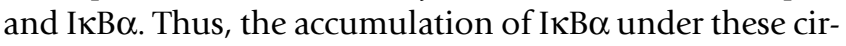
cumstances may down regulate the activity of p53.

Decreased p53-dependent transcription could limit the ability of p53 to trigger cellular apoptosis in the presence of inflammation since levels of targets of NF- $\mathrm{\kappa B}$, including $\mathrm{I} \kappa \mathrm{B} \alpha$, are up-regulated. If, in fact, $\mathrm{I} \kappa \mathrm{B} \alpha$ inhibits or dampens p53 function, cells could continue to proliferate and differentiate in the presence of an inflammatory event even if there is DNA damage or other cellular injury that would normally activate p53-dependent cell cycle arrest and apoptosis. Thus, a combination of inflammation and cellular damage could increase malignant transformation of cells since the threshold for p53 levels to trigger apoptosis may be elevated. It is notable that we know little about what thresholds regulate p53 function - in particular, what determines whether a cell repairs DNA and resumes transit through the cell cycle or dies. A molecule such as IKB $\alpha$ may be involved in influencing thresholddependent cell fate decisions. The observation that truncated $\mathrm{p} 53$ proteins may bind to $\mathrm{I} \kappa \mathrm{B} \alpha$ raises the possibility that short p53-related peptides could alter the binding between I $\mathrm{B} \mathrm{B} \alpha$ and $\mathrm{p} 53$, in turn altering a putative regulatory relationship between these proteins in vivo. Modulation of this regulatory interaction by pharmacologic or other means could potentially alter the balance between cellular proliferation and cell cycle arrest/apoptosis in the context of inflammation.

\section{Methods In vitro precipitation of $p 53$ and $I_{k} B \alpha$}

Bacterially produced $6 x$ His-tagged I $\mathrm{I} B \alpha($ His-І $\mathrm{K} B \alpha)$ was labeled in vitro with ${ }^{32} \mathrm{P}$ using $\left[\gamma^{32} \mathrm{P}\right] \mathrm{ATP}$ and Xenopus 
laevis p90 rsk (a gift of Dr. James Maller, Howard Hughes Memorial Institute and UCHSC, Denver CO) [80] and detected with polyclonal rabbit antiserum specific to the $\mathrm{N}$ - or C-terminus of IKB $\alpha$ as described (a gift of Dr. Warner Greene, the Gladstone Institute for Virology \& Immunology, UCSF, San Francisco, CA) GST-p53 produced from a pGEX construct in bacteris was incubated with hexahistidine-tagged I $\mathrm{B} \alpha$ purified as described in [44] in IP buffer buffer containing $25 \mathrm{mM}$ Hepes, $\mathrm{pH} 7.5,75 \mathrm{mM}$ $\mathrm{KCl}, 2.5 \mathrm{mM} \mathrm{MgCl}{ }_{2}, 0.1 \mathrm{mM}$ EDTA, $0.15 \% \mathrm{NP}-40$, and 1 $\mathrm{mM}$ DTT. Protein complexes were purified using either glutathione conjugated Sepharose beads to bind GST (Pharmacia) for GST-p53 or Protein A/G conjugated Sephadex beads (Oncogene Science, CA). Proteins were separated by polyacrylamide gel electrophoresis (PAGE) on either $10 \%$ or $12 \%$ gels which were dried and autoradiographed on photographic film (Fuji) for detection of radiolabeled protein or transferred to supported nitrocellulose or PVDF membrane and probed with antibodies using the Renaissance system for western blotting (NEN, Boston, MA). p53 specific monoclonal antibodies Ab1, $\mathrm{Ab} 2, \mathrm{Ab} 3, \mathrm{Ab} 5$, and Ab6 were obtained from Oncogene Science [81].

\section{Expression of IKB $\alpha$ alleles in cells}

COS cells and Akata cells were transiently transfected using Superfectin (Qiagen, Chatworth, CA) with expression vectors for IKB $\alpha$ alleles in an expression plasmid regulated by a CMV promoter (pCMV5) obtained from Dr. S.C. Sun (Penn State, Hershey, PA). COS cells were lysed in IP buffer (see above) and incubated with p53-pGEX. Overexpression and coprecipitation of I $\mathrm{K} \mathrm{B} \alpha$ proteins in COS cells was complicated by the apparent instability of some IкB $\alpha$ alleles $(\triangle \mathrm{A} 3, \Delta \mathrm{A} 4)$ these cells and lack of an association between other alleles $(\triangle \mathrm{A} 5)$ and p53-pGEX (unpublished observations). Following PAGE, $\Delta \mathrm{N} 1 \mathrm{I}$ I B $\alpha$ protein was detected using a rabbit polyclonal antisera directed at the C-terminus of I $\mathrm{B} \mathrm{B} \alpha$, while $\Delta \mathrm{C} 1$ І $\kappa \mathrm{B} \alpha$ protein was detected using a rabbit polyclonal antisera directed at the $\mathrm{N}$-terminus of IKB $\alpha$ in these experiments (antibodies to $\mathrm{N}$ - and C-termini of IкB $\alpha$ were a gift of Dr. W.C. Greene, the Gladstone Institute for Virology and Immunology and the University of California, San Francisco, CA).

\section{Transient transfection of Akata cells}

Akata cells were obtained from Dr. J. F. Jones (National Jewish Medical Research Center, Denver, CO). The identity of Akata cells was confirmed by expression of EBV lytic gene products following ligation of surface IgG (data not shown). Cells were cultured using standard conditions in RPMI medium (GIBCO-BRL) supplemented with 10\% fetal calf serum, penicillin/streptomycin $(100 \mathrm{U} / \mathrm{ml})$ and L-glutamine ( $2 \mathrm{mM}$ ). As previously reported, endogenous p53 protein was not detected in Akata cells by Western blotting with a rabbit polyclonal antisera directed at the entire p53 coding sequence (Santa Cruz Biologicals, Santa Cruz, CA) [21,81].

Akata cells were transiently transfected with plasmids using dextran sulfate (Pharmacia). p53 protein transiently expressed by plasmids transfected into Akata cells could be detected in nuclear extracts of transfected cells (data not shown). Levels of transfected wild-type IкB $\alpha$ protein were not detected by Western blotting above a high background of endogenous $I \kappa B \alpha$ proteins in Akata cells, although expression of $I \kappa B \alpha$ protein could be inferred by effects on transcription of NF- $\kappa B$ reporter genes. Akata were grown to a density of $1 \times 10^{6}$ cells $/ \mathrm{ml}$ and $1 \mathrm{ml}$ of cells for each experiment were transfected with Dextran. After transfection, cells were incubated in fresh culture medium for 24 hours prior to determination of luciferase activity.

\section{Luciferase assay}

A luciferase reporter gene regulated by 13 tandem copies of a p53 response element, denoted pG(13)PyLuc, or p21 promoter reporter, denoted WWP/Luc, were transfected into Akata cells in experiments at concentrations indicated. As noted in the text the relative effects of different alleles of IкB $\alpha$ upon p53 dependent luciferase expression varied with the relative ratios of expression vector for I $\mathrm{I} B \alpha$ to expression vector for $\mathrm{p} 53$. CMV-promoter driven $\mathrm{p} 53$ expression plasmids encoding wild-type p53 (pC53-SN3) and a DNA binding mutated p53 (pC53-CSX3 V193A) were obtained from Dr. B. Vogelstein, (Johns Hopkins University, Baltimore, MD). An expression plasmid encoding a carboxyl-terminus deleted p53 (pCEP4-353) was obtained from Dr. J. Pietenpol, Vanderbilt Univ., Memphis, TN). Plasmids were prepared using either the Promega (Madison, WI) or Qiagen (Chatsworth, CA) procedures with similar results.

A plasmid encoding a second form of luciferase (Renilla luciferase) driven by an SV40 promoter was used as an internal control for transfection efficiency and cell viability (pRL-SV40, Promega, Madison WI). Similar results were obtained without pRL transfection by normalization of luciferase activity to total cellular protein. Luciferase activity was measured using the Stop and Glo assay (Promega) and an Analytical Luminescence Laboratory luminometer (San Diego, CA). Each data point shown from luciferase assay experiments represents pooled data from at least three independent experiments. Standard error and significant differences $(\mathrm{p}<0.05$, indicated with an asterick, ${ }^{*}$ ) were as determined by the students t-test for multiple comparisons of data points using statistical software (SAS Institute Inc, Cary, NC). 


\section{Reticulocyte lysate expression and immunoprecipitation} For reticulocyte lysate expression and immunoprecipitation studies, I $\mathrm{\kappa} \mathrm{B} \alpha$ expression vectors were digested with $\mathrm{XbaI} /$ HindIII and ligated into the $\mathrm{XbaI} /$ HindIII site of $\mathrm{pBS}$ KS(Stratagene) to place the open reading frames downstream of a T7 RNA polymerase promoter element. These $\mathrm{I} \kappa \mathrm{B} \alpha$ constructs lack epitope tags. Vectors encoding p53 wild-type (SN3) and DNA binding mutant p53 protein (pBKS-273) for reticulocyte lysate expression were obtained from Dr. B. Vogelstein. ${ }^{35}$ S-Cysteine/methionine labelled I $\mathrm{B} \mathrm{B} \alpha$ and $\mathrm{p} 53$ proteins were produced in the TNT coupled transcription/translation system (Promega) using T7 RNA polymerase for wild-type p53 and I $\mathrm{I} B \alpha$ and T3 for mutant p53. $10 \mu \mathrm{l}$ of reticulocyte lysates, as indicated, were incubated in a total volume of $100 \mu \mathrm{l}$ IP buffer for 2 hours at $4{ }^{\circ} \mathrm{C}$. Antibodies were added and incubated for an additional 1 hour, and proteins were precipitated with Protein G plus/A Sephadex (Oncogene Science). Beads were washed once with $500 \mu \mathrm{l}$ IP buffer and proteins denatured in Laemmli sample buffer and separated on 10 or $12 \%$ PAGE gels dried and visualized by autoradiography. Despite possibly confounding variables due to the presence of the p65 (RelA) subunit of NF- $\mathrm{KB}$ and possibly other related factors in reticulocyte lysates (unpublished observations), a correlation was evident between the quantity of p53 coprecipitated with $\mathrm{I} \kappa \mathrm{B} \alpha$ and the relative effect of individual alleles upon in vivo p53 transcription in Akata cells. In particular, there was a lack of a detectable interaction between the ankyrin 3 deletion mutant of $\mathrm{I} \kappa \mathrm{B} \alpha$ and $\mathrm{p} 53$ in vivo or in vitro.

\section{Abbreviations used}

53BP2, p53 binding protein 2

ASPP2, apoptosis stimulating factor of p53-2

EBNA, Epstein-Barr nuclear antigen

EBV, Epstein-Barr virus

\section{Authors' contributions}

DHD and MN contributed equally to this work. Richard Ruhlen is acknowledged for his technical assistance.

\section{Acknowledgements}

This work was supported in part by funding from the American Cancer Society (Junior Faculty Award and Research and Clinical Investigation Award) and NIH grant GM049055 to LYG; and NIH grants HL36577, HL61005, and Al42246, and by EPA grant R835702 awarded to EWG.

\section{References}

I. Ko LJ, Prives C: p53: puzzle and paradigm. Genes Dev 1996, I 0:1054-72.

2. Lu H, Fisher RP, Bailey P, Levine AJ: The CDK7-cycH-p36 complex of transcription factor IIH phosphorylates p53, enhancing its sequence-specific DNA binding activity in vitro. Mol Cell Biol 1997, I 7:5923-34.
3. Ollmann M, Young LM, Di Como CJ, Karim F, Belvin M, Robertson S, Whittaker K, Demsky M, Fisher WW, Buchman A, Duyk G, Friedman L, Prives C, Kopczynski C: Drosophila p53 is a structural and functional homolog of the tumor suppressor p53. Cell 2000, I01:91-I01.

4. Shieh SY, Ikeda M, Taya Y, Prives C: DNA damage-induced phosphorylation of p53 alleviates inhibition by MDM2. Cell I997, 91:325-34.

5. Soussi T: The p53 tumor suppressor gene: from molecular biology to clinical investigation. Ann N Y Acad Sci 2000, 910:121-37. discussion 137-9

6. Chipuk JE, Green DR: p53's believe it or not: lessons on transcription-independent death. J Clin Immunol 2003, 23:355-6I.

7. Lakin ND, Jackson SP: Regulation of p53 in response to DNA damage. Oncogene 1999, 18:7644-55.

8. Sancar A, Lindsey-Boltz LA, Unsal-Kaccmaz K, Linn S: Molecular mechanisms of mammalian DNA repair and the DNA damage checkpoints. Annu Rev Biochem 2004, 73:39-85.

9. el-Deiry WS, Kern SE, Pietenpol JA, Kinzler KW, Vogelstein B: Definition of a consensus binding site for p53. Nat Genet 1992, I:45-9.

10. Mirza A, Wu Q, Wang L, McClanahan T, Bishop WR, Gheyas F, Ding W, Hutchins B, Hockenberry T, Kirschmeier P, Greene JR, Liu S: Global transcriptional program of p53 target genes during the process of apoptosis and cell cycle progression. Oncogene 2003, 22:3645-54.

II. Hulboy DL, Lozano G: Structural and functional analysis of p53: the acidic activation domain has transforming capability. Cell Growth Differ 1994, 5:1023-31.

12. Unger T, Mietz JA, Scheffner M, Yee CL, Howley PM: Functional domains of wild-type and mutant p53 proteins involved in transcriptional regulation, transdominant inhibition, and transformation suppression. Mol Cell Biol 1993, I3:5I86-94.

13. Kern SE, Pietenpol JA, Thiagalingam S, Seymour A, Kinzler KW, Vogelstein B: Oncogenic forms of p53 inhibit p53-regulated gene expression. Science 1992, 256:827-30.

14. Cho Y, Gorina S, Jeffrey PD, Pavletich NP: Crystal structure of a p53 tumor suppressor-DNA complex: understanding tumorigenic mutations. Science 1994, 265:346-55.

15. Brooks $\mathrm{CL}, \mathrm{Gu}$ W: Ubiquitination, phosphorylation and acetylation: the molecular basis for p53 regulation. Curr Opin Cell Biol 2003, I 5: I64-7I.

16. $\mathrm{Xu} \mathrm{Y}$ : Regulation of $\mathrm{p} 53$ responses by post-translational modifications. Cell Death Differ 2003, 10:400-3.

17. Dohoney KM, Guillerm C, Whiteford C, Elbi C, Lambert PF, Hager GL, Brady JN: Phosphorylation of p53 at serine 37 is important for transcriptional activity and regulation in response to DNA damage. Oncogene 2004, 23:49-57.

18. Gu J, Chen D, Rosenblum J, Rubin RM, Yuan ZM: Identification of a sequence element from p53 that signals for Mdm2-targeted degradation. Mol Cell Biol 2000, 20:1243-53.

19. Hupp TR, Sparks A, Lane DP: Small peptides activate the latent sequence-specific DNA binding function of p53. Cell 1995, 83:237-45.

20. Katayama H, Sasai K, Kawai H, Yuan ZM, Bondaruk J, Suzuki F, Fujii S, Arlinghaus RB, Czerniak BA, Sen S: Phosphorylation by aurora kinase $A$ induces Mdm2-mediated destabilization and inhibition of p53. Nat Genet 2004, 36:55-62.

21. Lohrum M, Scheidtmann KH: Differential effects of phosphorylation of rat p53 on transactivation of promoters derived from different p53 responsive genes. Oncogene 1996, 13:2527-39.

22. Sluss HK, Armata H, Gallant J, Jones SN: Phosphorylation of serine 18 regulates distinct $\mathrm{p} 53$ functions in mice. Mol Cell Biol 2004, 24:976-84.

23. Lill NL, Grossman SR, Ginsberg D, DeCaprio J, Livingston DM: Binding and modulation of $\mathrm{p} 53$ by $\mathrm{p} 300 / \mathrm{CBP}$ coactivators. Nature 1997, 387:823-7.

24. Scolnick DM, Chehab NH, Stavridi ES, Lien MC, Caruso L, Moran E, Berger SL, Halazonetis TD: CREB-binding protein and p300/ CBP-associated factor are transcriptional coactivators of the p53 tumor suppressor protein. Cancer Res 1997, 57:3693-6.

25. Dornan D, Shimizu H, Perkins ND, Hupp TR: DNA-dependent acetylation of $\mathrm{p} 53$ by the transcription coactivator $\mathrm{p} 300$. J Biol Chem 2003, 278: | 343 |-4l. 
26. Gu W, Roeder RG: Activation of p53 sequence-specific DNA binding by acetylation of the p53 C-terminal domain. Cell 1997, 90:595-606.

27. Samuels-Lev Y, O'Connor DJ, Bergamaschi D, Trigiante G, Hsieh JK, Zhong S, Campargue I, Naumovski L, Crook T, Lu X: ASPP proteins specifically stimulate the apoptotic function of p53. Mol Cell 200I, 8:78I-94.

28. Gorina S, Pavletich NP: Structure of the p53 tumor suppressor bound to the ankyrin and SH3 domains of 53BP2. Science 1996, 274: $1001-5$.

29. Krzywda S, Brzozowski AM, Higashitsuji H, Fujita J, Welchman R, Dawson S, Mayer RJ, Wilkinson AJ: The crystal structure of gankyrin, an oncoprotein found in complexes with cyclindependent kinase 4, a 19 s proteasomal ATPase regulator, and the tumor suppressors Rb and p53. J Biol Chem 2004, 279: $|54|-5$.

30. Crook T, Tidy JA, Vousden KH: Degradation of p53 can be targeted by HPV E6 sequences distinct from those required for p53 binding and trans-activation. Cell 1991, 67:547-56.

31. Scheffner M, Werness BA, Huibregtse JM, Levine AJ, Howley PM: The E6 oncoprotein encoded by human papillomavirus types 16 and 18 promotes the degradation of p53. Cell 1990, 63: $1129-36$

32. Doniger J, Muralidhar S, Rosenthal LJ: Human cytomegalovirus and human herpesvirus 6 genes that transform and transactivate. Clin Microbiol Rev 1999, I 2:367-82.

33. Farrell PJ, Allan GJ, Shanahan F, Vousden KH, Crook T: p53 is frequently mutated in Burkitt's lymphoma cell lines. Embo J 1991, 10:2879-87.

34. Mauser A, Saito S, Appella E, Anderson CW, Seaman WT, Kenney S: The Epstein-Barr virus immediate-early protein BZLFI regulates p53 function through multiple mechanisms. J Virol 2002, 76: I 2503-12.

35. Baeuerle PA, Henkel T: Function and activation of NF-kappa B in the immune system. Annu Rev Immunol 1994, I 2: |4 |-79.

36. Baichwal VR, Baeuerle PA: Activate NF-kappa B or die? Curr Biol 1997, 7:R94-6.

37. Green DR: Death and NF-kappaB in $\mathbf{T}$ cell activation: life at the edge. Mol Cell 2003, I I:55I-2.

38. Kawakami K, Scheidereit C, Roeder RG: Identification and purification of a human immunoglobulin-enhancer-binding protein (NF-kappa B) that activates transcription from a human immunodeficiency virus type I promoter in vitro. Proc Natl Acad Sci U S A 1988, 85:4700-4.

39. Pierce JW, Lenardo M, Baltimore D: Oligonucleotide that binds nuclear factor NF-kappa B acts as a lymphoid-specific and inducible enhancer element. Proc Natl Acad Sci U S A 1988, 85: $\mid 482-6$.

40. Nolan GP, Ghosh S, Liou HC, Tempst P, Baltimore D: DNA binding and I kappa $B$ inhibition of the cloned $p 65$ subunit of NFkappa B, a rel-related polypeptide. Cell I991, 64:96I-9.

4I. Beg AA, Ruben SM, Scheinman RI, Haskill S, Rosen CA, Baldwin AS Jr: I kappa $B$ interacts with the nuclear localization sequences of the subunits of NF-kappa B: a mechanism for cytoplasmic retention. Genes Dev 1992, 6:1899-913.

42. Alkalay I, Yaron A, Hatzubai A, Orian A, Ciechanover A, Ben-Neriah Y: Stimulation-dependent I kappa B alpha phosphorylation marks the NF-kappa B inhibitor for degradation via the ubiquitin-proteasome pathway. Proc Natl Acad Sci U S A 1995, 92:10599-603.

43. DiDonato J, Mercurio F, Rosette C, Wu-Li J, Suyang H, Ghosh S, Karin M: Mapping of the inducible IkappaB phosphorylation sites that signal its ubiquitination and degradation. Mol Cell Biol 1996, 16:1295-304.

44. Ghoda L, Lin X, Greene WC: The 90-kDa ribosomal S6 kinase (pp90rsk) phosphorylates the $\mathbf{N}$-terminal regulatory domain of IkappaBalpha and stimulates its degradation in vitro. J Biol Chem 1997, 272:2128I-8.

45. Sun S, Elwood J, Greene WC: Both amino- and carboxyl-terminal sequences within I kappa $B$ alpha regulate its inducible degradation. Mol Cell Biol I996, I6:1058-65.

46. Grisham MB, Palombella VJ, Elliott PJ, Conner EM, Brand S, Wong HL, Pien C, Mazzola LM, Destree A, Parent L, Adams J: Inhibition of NFkappa $B$ activation in vitro and in vivo: role of 265 proteasome. Methods Enzymol 1999, 300:345-63.
47. Rodriguez MS, Wright J, Thompson J, Thomas D, Baleux F, Virelizier JL, Hay RT, Arenzana-Seisdedos F: Identification of lysine residues required for signal-induced ubiquitination and degradation of I kappa B-alpha in vivo. Oncogene 1996, I 2:2425-35.

48. Karin M, Ben-Neriah Y: Phosphorylation meets ubiquitination: the control of NF-[kappa]B activity. Annu Rev Immunol 2000 , I 8:62I-63.

49. Scherer DC, Brockman JA, Chen Z, Maniatis T, Ballard DW: Signalinduced degradation of I kappa $B$ alpha requires site-specific ubiquitination. Proc Natl Acad Sci U S A 1995, 92: I | 259-63.

50. Phelps CB, Sengchanthalangsy LL, Huxford T, Ghosh G: Mechanism of I kappa B alpha binding to NF-kappa B dimers. J Biol Chem 2000, 275:29840-6.

51. Beg AA, Sha WC, Bronson RT, Baltimore D: Constitutive NFkappa $B$ activation, enhanced granulopoiesis, and neonatal lethality in I kappa B alpha-deficient mice. Genes Dev 1995, 9:2736-46.

52. Klement JF, Rice NR, Car BD, Abbondanzo SJ, Powers GD, Bhatt PH, Chen $\mathrm{CH}$, Rosen CA, Stewart CL: IkappaBalpha deficiency results in a sustained NF-kappaB response and severe widespread dermatitis in mice. Mol Cell Biol 1996, I6:234I-9.

53. Webster GA, Perkins ND: Transcriptional cross talk between NF-kappaB and p53. Mol Cell Biol 1999, 19:3485-95.

54. Egan LJ, Eckmann L, Greten FR, Chae S, Li ZW, Myhre GM, Robine S, Karin M, Kagnoff MF: IkappaB-kinasebeta-dependent NF-kappaB activation provides radioprotection to the intestinal epithelium. Proc Natl Acad Sci U S A 2004, I 0 I :2452-7.

55. Holmes-McNary MQ, Baldwin AS Jr, Zeisel SH: Opposing regulation of choline deficiency-induced apoptosis by $\mathrm{p} 53$ and nuclear factor kappaB. J Biol Chem 200I, 276:4 I I 97-204.

56. Jung $M$, Zhang $Y$, Lee $S$, Dritschilo $A$ : Correction of radiation sensitivity in ataxia telangiectasia cells by a truncated I kappa Balpha. Science 1995, 268:1619-21.

57. Perkins ND: Oncogenes, tumor suppressors and p52 NF-kappaB. Oncogene 2003, 22:7553-6.

58. Rocha S, Campbell KJ, Perkins ND: p53- and Mdm2-independent repression of NF-kappa B transactivation by the ARF tumor suppressor. Mol Cell 2003, I 2: I5-25.

59. Ryan KM, Ernst MK, Rice NR, Vousden KH: Role of NF-kappaB in p53-mediated programmed cell death. Nature 2000 , 404:892-7.

60. Jeffrey PD, Gorina S, Pavletich NP: Crystal structure of the tetramerization domain of the p53 tumor suppressor at 1.7 angstroms. Science 1995, 267:1498-502.

61. Muller CW, Harrison SC: The structure of the NF-kappa B p50:DNA-complex: a starting point for analyzing the Rel family. FEBS Lett 1995, 369: I 13-7.

62. Muller CW, Rey FA, Sodeoka M, Verdine GL, Harrison SC: Structure of the NF-kappa B p50 homodimer bound to DNA. Nature 1995, 373:311-7.

63. Yang JP, Hori M, Takahashi N, Kawabe T, Kato H, Okamoto T: NFkappaB subunit p65 binds to 53BP2 and inhibits cell death induced by 53BP2. Oncogene 1999, I 8:5177-86.

64. Dreyfus DH, Nagasawa M, Kelleher CA, Gelfand EW: Stable expression of Epstein-Barr virus BZLF-I-encoded ZEBRA protein activates $p 53$-dependent transcription in human Jurkat T-lymphoblastoid cells. Blood 2000, 96:625-34.

65. Gutsch DE, Holley-Guthrie EA, Zhang Q, Stein B, Blanar MA, Baldwin AS, Kenney SC: The bZIP transactivator of Epstein-Barr virus, BZLFI, functionally and physically interacts with the p65 subunit of NF-kappa B. Mol Cell Biol 1 994, I 4: | 939-48.

66. Morrison TE, Mauser A, Klingelhutz A, Kenney SC: Epstein-Barr virus immediate-early protein BZLFI inhibits tumor necrosis factor alpha-induced signaling and apoptosis by downregulating tumor necrosis factor receptor I. J Virol 2004, 78:544-9.

67. Sun SC, Elwood J, Beraud C, Greene WC: Human T-cell leukemia virus type I Tax activation of NF-kappa B/Rel involves phosphorylation and degradation of I kappa B alpha and RelA (p65)-mediated induction of the c-rel gene. Mol Cell Biol 1994, 14:7377-84.

68. Chang NS: The non-ankyrin C terminus of Ikappa Balpha physically interacts with p53 in vivo and dissociates in response to apoptotic stress, hypoxia, DNA damage, and transforming growth factor-beta I-mediated growth suppression. J Biol Chem 2002, 277:10323-31. 
69. Zhou M, Gu L, Zhu N, Woods WG, Findley HW: Transfection of a dominant-negative mutant NF-kB inhibitor (IkBm) represses p53-dependent apoptosis in acute lymphoblastic leukemia cells: interaction of $\mathrm{IkBm}$ and p53. Oncogene 2003, 22:8I37-44.

70. Foo SY, Nolan GP: NF-kappaB to the rescue: RELs, apoptosis and cellular transformation. Trends Genet 1999, 15:229-35.

7I. Hogue CW: Cn3D: a new generation of three-dimensional molecular structure viewer. Trends Biochem Sci 1997, 22:3|4-6.

72. Malek S, Huang DB, Huxford T, Ghosh S, Ghosh G: X-ray crystal structure of an IkappaBbeta x NF-kappaB p65 homodimer complex. I Biol Chem 2003, 278:23094-100.

73. Merrick BA, Zhou W, Martin KJ, Jeyarajah S, Parker CE, Selkirk JK, Tomer KB, Borchers CH: Site-specific phosphorylation of human $\mathrm{p} 53$ protein determined by mass spectrometry. Biochemistry 200I, 40:4053-66.

74. Bessard AC, Garay E, Lacronique V, Legros $Y$, Demarquay C, Houque A, Portefaix JM, Granier C, Soussi T: Regulation of the specific DNA binding activity of Xenopus laevis p53: evidence for conserved regulation through the carboxy-terminus of the protein. Oncogene 1998, 16:883-90.

75. Sakaguchi K, Sakamoto H, Xie D, Erickson JW, Lewis MS, Anderson $\mathrm{CW}$, Appella E: Effect of phosphorylation on tetramerization of the tumor suppressor protein p53. J Protein Chem 1997, 16:553-6.

76. Akslen LA, Morkve O: Expression of p53 protein in cutaneous melanoma. Int J Cancer 1992, 52: I3-6.

77. Dreyfus DH, Nagasawa M, Pratt JC, Kelleher CA, Gelfand EW: Inactivation of NF-kappaB by EBV BZLF-I-encoded ZEBRA protein in human T cells. J Immunol 1999, 163:626I-8.

78. Bohuslav J, Chen LF, Kwon H, Mu Y, Greene WC: p53 induces NFkappaB activation by an IkappaB kinase-independent mechanism involving phosphorylation of $\mathrm{p} 65$ by ribosomal 56 kinase I. J Biol Chem 2004, 279:26 I I5-25.

79. Levitskaya J, Sharipo A, Leonchiks A, Ciechanover A, Masucci MG: Inhibition of ubiquitin/proteasome-dependent protein degradation by the Gly-Ala repeat domain of the Epstein-Barr virus nuclear antigen I. Proc Natl Acad Sci U S A 1997, 94:|26|6-2|.

80. Stefanovic D, Erikson E, Pike LJ, Maller JL: Activation of a ribosomal protein $\mathbf{S 6}$ protein kinase in Xenopus oocytes by insulin and insulin-receptor kinase. Embo ] 1986, 5:157-60.

81. Bonsing BA, Corver WE, Gorsira MC, van Vliet M, Oud PS, Cornelisse CJ, Fleuren GJ: Specificity of seven monoclonal antibodies against p53 evaluated with Western blotting, immunohistochemistry, confocal laser scanning microscopy, and flow cytometry. Cytometry 1997, 28: I I-24.

Publish with Bio Med Central and every scientist can read your work free of charge

"BioMed Central will be the most significant development for disseminating the results of biomedical research in our lifetime. "

Sir Paul Nurse, Cancer Research UK

Your research papers will be:

- available free of charge to the entire biomedical community

- peer reviewed and published immediately upon acceptance

- cited in PubMed and archived on PubMed Central

- yours - you keep the copyright
BiolMedcentral 